OPEN ACCESS

Edited by:

Kevin M. Kocot,

University of Alabama, United States

Reviewed by:

Christopher Nicolai Roterman, University of Oxford, United Kingdom Jon Thomassen Hestetun,

Norwegian Research Institute (NORCE), Norway

*Correspondence: Katharina Kniesz katharina.kniesz@senckenberg.de

Specialty section

This article was submitted to Deep-Sea Environments and Ecology, a section of the journal Frontiers in Marine Science

Received: 02 August 2021 Accepted: 26 November 2021 Published: 06 January 2022

Citation:

Kniesz K, Jażdżewska AM, Martínez Arbizu P and Kihara TC (2022) DNA Barcoding of Scavenging Amphipod Communities at Active and Inactive Hydrothermal Vents in the Indian Ocean.

Front. Mar. Sci. 8:752360. doi: 10.3389/fmars.2021.752360

\section{DNA Barcoding of Scavenging Amphipod Communities at Active and Inactive Hydrothermal Vents in the Indian Ocean}

\author{
Katharina Kniesz ${ }^{1,2 *}$, Anna Maria Jażdżewska ${ }^{3}$, Pedro Martínez Arbizu ${ }^{1,2}$ and \\ Terue Cristina Kihara ${ }^{4}$
}

\begin{abstract}
${ }^{1}$ Senckenberg am Meer, German Centre for Marine Biodiversity Research, Wilhelmshaven, Germany, ${ }^{2}$ Carl von Ossietzky Universität Oldenburg, Oldenburg, Germany, ${ }^{3}$ Department of Invertebrate Zoology and Hydrobiology, Faculty of Biology and Environmental Protection, University of Łódź, Łódź, Poland, ${ }^{4}$ INES Integrated Environmental Solutions UG, Wilhelmshaven, Germany
\end{abstract}

Hydrothermal vent areas have drawn increasing interest since they were discovered in 1977. Because of chemoautotrophic bacteria, they possess high abundances of vent endemic species as well as many non-vent species around the fields. During the survey conducted by the Bundesanstalt für Geowissenschaften und Rohstoffe (Federal Institute for Geosciences and Natural Resources, BGR) to identify inactive polymetallic sulfide deposits along Central and Southeast Indian Ridges, the INDEX project studied the scavenging amphipod community at three newly discovered hydrothermal fields. A sample consisting of 463 representatives of Amphipoda (Malacostraca: Crustacea) was collected by means of baited traps in active and inactive vents of three different sites and subsequently studied by both morphological and genetic methods. Molecular methods included the analysis of two mitochondrial (cytochrome $c$ oxidase subunit I [COI] and 16S rRNA) and one nuclear (18S rRNA) genes. By six delimitation methods, 22 molecular operational taxonomic units (MOTUs) belonging to 12 genera and 10 families were defined. The existence of potential species complexes was noted for the representatives of the genus Paralicella. The inactive site, where 19 species were found, showed higher species richness than did the active one, where only 10 taxa were recorded. Seven genera, Ambasiopsis, Cleonardo, Eurythenes, Parandania, Pseudonesimus, Tectovalopsis, and Valettiopsis, were observed only at inactive sites, whereas Haptocallisoma, was collected exclusively at active ones. The species Abyssorchomene distinctus (Birstein and Vinogradov, 1960), Hirondellea brevicaudata Chevreux, 1910, and Hirondellea guyoti Barnard and Ingram, 1990, have been previously reported from vent sites in the Atlantic or Pacific oceans. The present study provides the first report of Eurythenes magellanicus $(H$. Milne Edwards, 1848) and five other already described species in the Indian Ocean. The addition of 356 sequences strongly increases the number of amphipod barcodes 
in reference databases and provides for the first time COI barcodes for Cleonardo neuvillei Chevreux, 1908, Haptocallisoma abyssi (Oldevig, 1959), Hirondellea guyoti, Tectovalopsis fusilus Barnard and Ingram, 1990, and the genera Haptocallisoma, Pseudonesimus, and Valettiopsis.

Keywords: Indian Ocean, hydrothermal vent, barcoding, genetic diversity, Amphipoda, abyssal, deep sea, baited trap

\section{INTRODUCTION}

Much less is known about hydrothermal vents and the deep sea in general than about terrestrial and shallow-water ecosystems. The first hydrothermal vent was discovered in 1977 along the Galapagos Rift (Lonsdale, 1977). Over the past 50 years the study of hydrothermal vents has progressed, but most studied vents are located in the Pacific and Atlantic oceans (German and Von Damm, 2006). The first vent fields on the Central Indian Ridge were discovered in 2000 and 2001 (Gamo et al., 2001; Hashimoto et al., 2001; Van Dover et al., 2001). Compared to that of Atlantic and Pacific vents, the fauna of the Indian Ocean vents is underexplored (Ingole and Koslow, 2005; Nakamura et al., 2012).

Discovery of the first hydrothermal vent field changed the view of primary production in the world's oceans fundamentally (De Busserolles et al., 2009). At hydrothermal vent fields chemoautotrophic bacteria use inorganic substances such as ferrous iron, hydrogen sulfides, and methane for primary production (De Busserolles et al., 2009). They occur free living or in symbiosis with eukaryotic species. Because this food source is independent of primary production in the photic zone, many endemic species are found in these fields, but non-vent species also occur in higher abundance around the vents than in the rest of the deep sea (Podowski et al., 2009).

Kato et al. (2010) revealed that abundance, diversity, and activity of microbial communities within sulfide structures of inactive vents are higher than or comparable to those of active vents. Inactive vent fields consist of polymetallic sulfides, like active vents, but without any detectable emissions (Van Dover, 2011) and are located within or close to active vent fields. Inactive fields are often inhabited by a mix of general deep-sea species, inactive vent species, and a reduced number of vent species, which are found in low abundances (Erickson et al., 2009; Levin et al., 2009; Collins et al., 2012; Boschen et al., 2016).

The high food availability at active and inactive vent fields leads to the presence of specific scavenging megafaunal species (Gerdes et al., 2019a). In this benthic deep-sea environment food is a limiting factor, and scavengers play an important role in recycling the organic carbon reaching the ocean floor and providing it as food for higher trophic levels. Marine scavengers are found throughout all phyla and habitats (King et al., 2007). They include some fishes and many invertebrate taxa like ophiuroids, asteroids, holothurians, decapods, isopods, and amphipods. Scavenging amphipods have been collected in great numbers by means of baited traps (Perrone et al., 2002; Jamieson et al., 2009; Gallo et al., 2015) and include mainly the representatives of Lysianassoidea, from the genera Abyssorchomene, Anonyx, Cyclocaris, Cyphocaris, Eurythenes, Hirondellea, Orchomene, Orchomenella, and the alicelloid Paralicella (Shulenberger and Hessler, 1974; SainteMarie, 1986; Christiansen, 1996; Legeżyńska et al., 2000; Blankenship and Levin, 2007; Duffy et al., 2016).

Deep-sea scavenging amphipods are adapted to endure the extreme conditions and limitations, using chemosensory appendages to detect and take their bait (Tamburri and Barry, 1999). As one limiting factor in deep-sea environment is food, some scavenging amphipods complement their necrophagy with detritivory, carnivory, and even cannibalism (Blankenship and Levin, 2007; Jamieson et al., 2010; Havermans and Smetacek, 2018). Another recent finding of cellulase in one scavenging species, Hirondellea gigas (Birstein and Vinogradov, 1955), suggests that it may digest wood debris, although no wood particles were recorded in its digestive tract (Kobayashi et al., 2012). Other vent amphipod species, also well-adapted to their environment, feed on the microbes present there.

Ventiella sulfuris Barnard and Ingram, 1990, is the most abundant amphipod species at the Eastern Pacific Rise vent fields. It lives in symbiosis with microbial communities inhabiting its midgut and hindgut and is known to be vent endemic (Corbari et al., 2012). Another vent endemic amphipod species, Dulichiopsis dianae Corbari and Sorbe, 2017, was detected at hydrothermal vents along the Mid-Atlantic Ridge (Corbari and Sorbe, 2017), but several amphipods are reported to be caught at or near hydrothermal vent systems all over the world (Barnard and Ingram, 1990; Desbruyères et al., 2006; Bellan-Santini, 2007; Larsen, 2007) that are not necessarily vent endemic (*We use "endemic" to refer to species occurring within a biotope and not within a geographical region; as per Wolff, 2005).

Baited traps were deployed during INDEX 2018, providing the opportunity to examine scavenging amphipods at the vent fields in the Indian Ocean. The objectives of the present study were: (1) to identify scavenging amphipod species at the Southeast and Central Indian ridges and (2) to determine whether the distribution pattern of recorded species is associated with the hydrothermal activity.

\section{MATERIALS AND METHODS}

\section{Sampling}

Our study was part of the INDEX 2018 expedition on Dutch RV Pelagia. The Southeast and the Central Indian Ridges are located in the Indian Ocean about 1,400 km southeast of the island of Mauritius. At each of three newly discovered vent fields, an amphipod trap was placed by the Canadian Remotely 
Operated Vehicle (ROV) ROPOS. It was deployed three times by the manipulators and placed traps at one inactive (AT1: on the Southeast Indian Ridge) and two active areas (AT2: on the Southeast Indian Ridge; AT3: on the Central Indian Ridge). The distance between AT1 and AT2 was approximately $342 \mathrm{~km}$, that between AT2 and AT3, $210 \mathrm{~km}$ (Table 1 and Figure 1).

To attract the scavenging fauna, fish and cat food were enclosed in a net $(40 \mu \mathrm{m}$ mesh size $)$ inside each trap. After 7-29 $\mathrm{h}$ the trap was recovered by the ROV (Table 1). On shipboard, the larger individuals were hand-picked, and the smaller ones, including the sediment were, passed through a $40-\mu \mathrm{m}$ sieve, and all samples preserved in $96 \%$ undenatured ethanol.

\section{Morphological Analyses}

All intact specimens were studied morphologically. Badly damaged specimens were not counted and processed. The material is stored at the German Centre for Marine Biodiversity Research (DZMB) in Wilhelmshaven.

In the first step all amphipods were identified by means of a Leica M 125 stereomicroscope and the relevant literature (Chevreux, 1889; Shulenberger and Barnard, 1976; Lincoln, 1979; Barnard and Ingram, 1990; Barnard and Karaman, 1991; Bousfield and Hendrycks, 1995; Berge and Vader, 2001; Hendrycks, 2007; Lowry and De Broyer, 2008; Lowry and Stoddart, 2010; Lowry and Kilgallen, 2014; d'Udekem d'Acoz and Havermans, 2015; Horton and Thurston, 2015; Kilgallen and Lowry, 2015). For purposes of the morphological work, one representative of each recognized morphospecies was dissected and all appendages were mounted on permanent slides with polyvinyl-lactophenol containing lignin pink.

Undescribed or unknown species were named according to the nomenclature rules of Sigovini et al. (2016). Because of taxonomic problems, specimens of the genus Paralicella were divided into two morphological groups, and "sp. group" identifier was added to the name. In addition, a unique species code was given to the species where the species-level identity was not known or the species was new to science (Horton et al., 2021). This species code is a standardized code in the INDEX project and combines storage, year of publication, and a serial number.

\section{Photographing and Confocal Imaging}

The 279 specimen used for molecular analysis were photographed with a Leica M 125 stereomicroscope equipped with a Leica MC 170 HD camera. In addition, one representative of each morphospecies [excluding the largest species, Eurythenes magellanicus (H. Milne Edwards, 1848)] was chosen for confocal laser scanning microscopy (Supplementary Table 1). The specimens were stained with a 1:1 solution of acid fuchsin and Congo red overnight according to procedures adapted from Michels and Büntzow (2010), then temporarily mounted on an objective slide with glycerine and self-adhesive reinforcement rings to support the coverslip (Michels and Büntzow, 2010). For larger specimens, double-sided tape pieces and some drops of Karo $^{\circledR}$ light corn syrup were mounted between slide and coverslip (Brix et al., 2018).

The scanning was performed with a Leica TCS SP5 equipped with a Leica DM5000 B upright microscope and three visiblelight lasers (DPSS $10 \mathrm{~mW} 561 \mathrm{~nm}$; HeNe $10 \mathrm{~mW} 633 \mathrm{~nm}$; Ar $100 \mathrm{~mW} 458 \mathrm{~nm}, 476 \mathrm{~nm}, 488 \mathrm{~nm}$, and $514 \mathrm{~nm}$ ), combined with the software LAS AF 2.2.1. Leica Application Suite Advanced Fluorescence (Kihara and Rocha, 2013) at the DZMB in Wilhelmshaven. To obtain the images, we used objective HCX PL APO CS $10.0 \times 0.40$ DRY UV and $561 \mathrm{~nm}$ excitation wavelength with $80 \%$ acousto-optic tuneable filter. Series of stacks were created with a resolution of $2,048 \times 2,048$ pixels. The final images were obtained by means of maximum projection. Finally, the individual images were merged in Adobe ${ }^{\circledR}$ Photoshop ${ }^{\circledR}$ 21.1.3 and edited for contrast and brightness.

\section{Molecular Studies}

For each recognized morphospecies a representation of one to ten individuals was chosen for DNA barcoding. In cases where taxa caused morphological identification problems the number of analyzed specimens was increased or all specimens were used. For 279 specimens genomic DNA was extracted from one pleopod or pereopod (for smaller specimens), which was removed and treated with $30 \mu \mathrm{l}$ of CHELEX (BIO-RAD Insta Gene Matrix) for $20 \mathrm{~min}$ at $56^{\circ} \mathrm{C}$ and $10 \mathrm{~min}$ at $99^{\circ} \mathrm{C}$. For some samples the additional purification of the chelex extract was performed with columns (E.Z.N.A. ${ }^{\circledR}$ Mollusc DNA Kit, NucleoSpin ${ }^{\circledR}$ Tissue) according to the manufacturer's protocol.

Polymerase chain reactions of the mitochondrial cytochrome $c$ oxidase subunit I (COI) and mitochondrial ribosomal large subunit (16S) were performed with amphipod-specific primers (Table 2) and protocols provided by their authors (Costa et al., 2009; Lörz et al., 2018). The fragment of the COI gene was amplified for all chosen individuals, whereas $16 \mathrm{~S}$ and the nuclear small ribosomal subunit (18S) was amplified on a subset of specimens. For $18 \mathrm{~S}$ the universal primer set $18 \mathrm{SE}$ and $18 \mathrm{SL}$ (Table 2) was used, and the polymerase chain reaction conditions

TABLE 1 | Deployed amphipod traps with station ID, coordinates, ridge (Central Indian Ridge = CIR, Southeast Indian Ridge = SEIR), hydrothermal activity, collection depth, the deployment time of the trap on the seafloor and the measured environmental parameters (temperature, salinity, and pH-value).

\begin{tabular}{|c|c|c|c|c|c|c|c|c|c|}
\hline Trap No. & Station ID & Coordinates & Ridge & $\begin{array}{c}\text { Hydrothermal } \\
\text { activity }\end{array}$ & $\begin{array}{l}\text { Sampled } \\
\text { depth (m) }\end{array}$ & $\begin{array}{c}\text { Time on } \\
\text { bottom (h) }\end{array}$ & $\begin{array}{c}\text { Temperature } \\
\left({ }^{\circ} \mathrm{C}\right)\end{array}$ & Salinity (psu) & $\mathrm{pH}$ \\
\hline AT1 & 118_067RO_AT1 & $\begin{array}{c}27^{\circ} 39^{\prime} \mathrm{S}, 73^{\circ} \\
53^{\prime} \mathrm{E}\end{array}$ & SEIR & inactive & 2,508 & 29 & 1.79 & 34.72 & 3.10 \\
\hline AT2 & 118_075RO_AT1 & $\begin{array}{c}27^{\circ} 15^{\prime} \mathrm{S}, 72^{\circ} \\
43^{\prime} \mathrm{E}\end{array}$ & SEIR & active & 2,919 & 7 & 1.71 & 34.73 & 3.10 \\
\hline AT3 & 118_099RO_AT1 & $\begin{array}{c}25^{\circ} 28^{\prime} \mathrm{S}, 69^{\circ} \\
56^{\prime} \mathrm{E}\end{array}$ & $\mathrm{CIR}$ & active & 2,629 & 22 & 2.0 & 34.69 & 3.09 \\
\hline
\end{tabular}




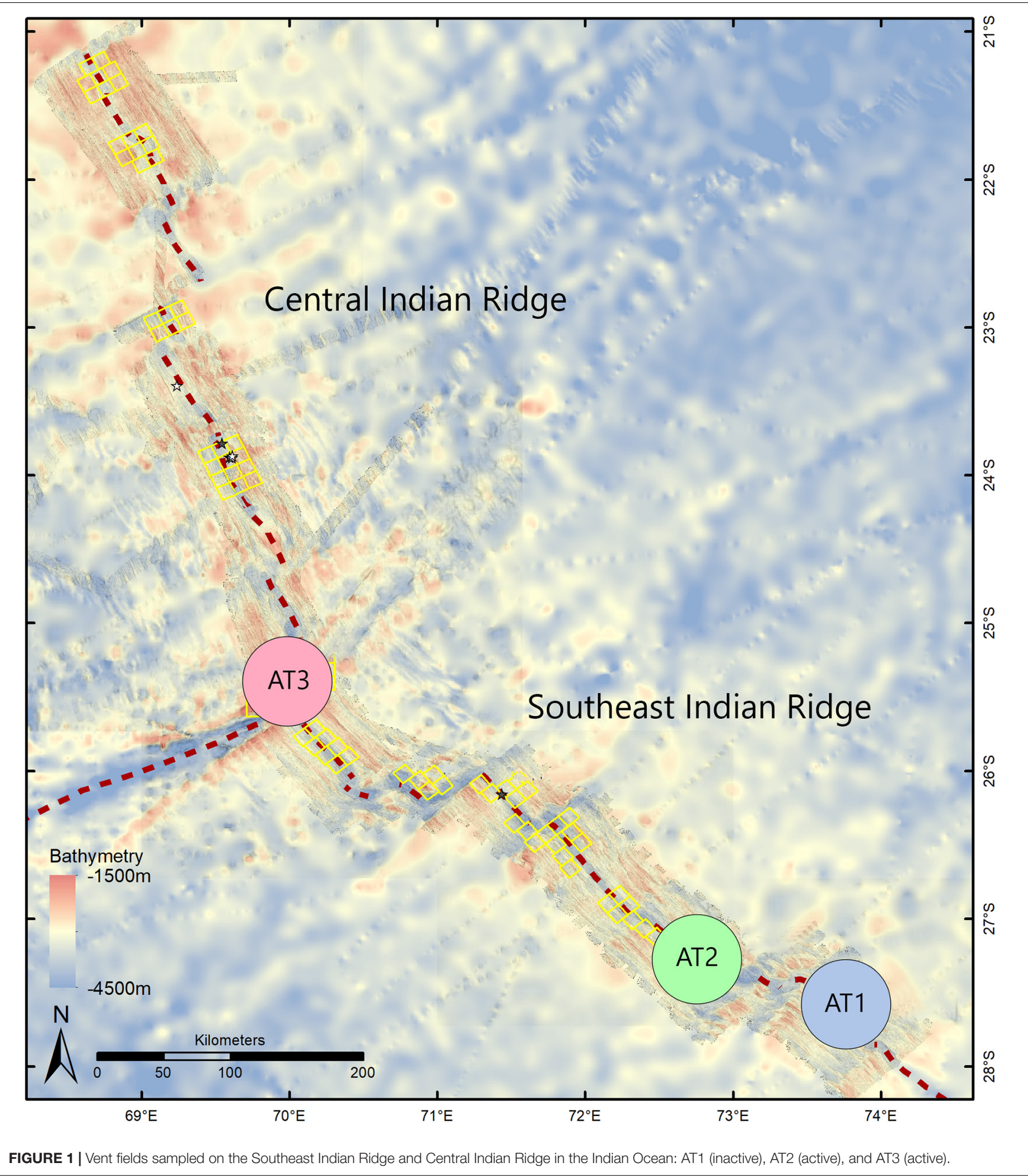

were as follows: initial denaturation at $94^{\circ} \mathrm{C}$ for $3 \mathrm{~min} ; 45$ cycles of $30 \mathrm{~s}$ at $94^{\circ} \mathrm{C}, 45 \mathrm{~s}$ at an annealing temperature of $55^{\circ} \mathrm{C}$, and $1 \mathrm{~min}$ at $72^{\circ} \mathrm{C}$; final elongation for $3 \mathrm{~min}$ at $72^{\circ} \mathrm{C}$. To all primers M13 tails were added to provide defined nucleotide sequences for sequencing (Table 2). All amplified products were purified with Exo-SAP-IT ${ }^{\circledR}$. Afterwards they were sequenced by Macrogen Inc., The Netherlands. In order to assemble long DNA fragments of the $18 \mathrm{~S}$ gene, we sequenced amplified fragments with intermediate primers synthetized by Macrogen Inc. (Table 2) in addition. 
TABLE 2 | Primers used in the present study.

\begin{tabular}{|c|c|c|c|c|}
\hline Gene & Name & Sequence $5^{\prime}-3^{\prime}$ & Direction & References \\
\hline \multirow[t]{2}{*}{$\mathrm{COI}$} & UCOIR & ACWAAYCAYAAAGAYATYGG & Forward & Costa et al., 2009 \\
\hline & UCOIF & TAWACTTCDGGRTGRCCRAAAAAYCA & Reverse & Costa et al., 2009 \\
\hline \multirow[t]{2}{*}{$16 S$} & 16SFt_amp & GCRGTATIYTRACYGTGCTAAGG & Forward & Lörz et al., 2018 \\
\hline & 16SRt_amp2 & CTGGCTTAAACCGRTYTGAACTC & Reverse & Lörz et al., 2018 \\
\hline \multirow[t]{4}{*}{$18 S$} & 18SE & CTGGTTGATCCTGCCAGT & Forward & Hillis and Dixon, 1991 \\
\hline & $18 S L$ & CACCTACGGAAACCTTGTTACGACTT & Reverse & Hamby and Zimmer, 1988 \\
\hline & $F-566$ & CAGCAGCCGCGGTAATTCC & Forward, intermediate & Hadziavdic et al., 2014 \\
\hline & $R-1200$ & CCCGTGTTGAGTCAAATTAAGC & Reverse, intermediate & Hadziavdic et al., 2014 \\
\hline \multirow[t]{2}{*}{ M13 } & M13-FP & TGTAAAACGACGGCCAGT & Forward & Schuelke, 2000 \\
\hline & M13R-pUC & CAGGAAACAGCTATGAC & Reverse & Messing, 1983 \\
\hline
\end{tabular}

Each primer was added by the universal M13 tail (M13-FP, M13R-pUC).

The resulting sequences were edited with Geneious Prime ${ }^{\circledR}$ 2020.1.2 (Kearse et al., 2012) as a check for ambiguities and errors. All edited sequences were aligned and trimmed with MAFFT v7.450 (Katoh et al., 2002) alignment in Geneious by the automatic algorithm. Afterward, similarity analyses with Blastn (Altschul et al., 1990) search against GenBank and the Barcode of Life Data System (BOLD, Ratnasingham and Hebert, 2007) were performed. Short sequences and sequences with bad quality were not included in the analysis. All sequences were deposited in GenBank with the accession numbers COI, MZ197178MZ197435; 16S, MZ197436-MZ197490; and 18S, MZ197491MZ197533. Relevant voucher information, pictures, taxonomic classifications, and sequences were deposited in the dataset "DS-INMAC01" in BOLD (Ratnasingham and Hebert, 2007) ${ }^{1}$ (doi: 10.5883/DS-INMAC01) (GenBank accession numbers: Supplementary Table 1).

\section{Species Delimitation and Phylogenetic Analyses}

To infer the number of species in the present study, we delimited them according to their morphology by grouping them to morphospecies and by analyzing genetic distances of molecular taxonomic units (MOTUs). The MOTUs were delimited on COI sequences by five methods-three distance-based and two treebased.

Because, for some of the delimitation methods, a threshold is mandatory, intra- and interspecific distances for our dataset were first calculated by the Barcode Gap Analysis provided by BOLD (distance model: Kimura 2 Parameter; alignment options: BOLD aligner; ambiguous base/gap handling: pairwise deletion). As a result the threshold value for the speciesdelimitation methods was set at 0.976 or $97.6 \%$ (mean intraspecific divergence is 2.4 after exclusion of the species complex) (Supplementary Figures 1, 2 and Supplementary Table 2), but note that the threshold for separating species within marine Amphipoda reported in the literature ranges from $93 \%$ to $97 \%$ and is suggested to be family specific (Knox et al., 2012; Tempestini et al., 2018; Mohrbeck et al., 2021).

\footnotetext{
${ }^{1}$ http://www.boldsystems.org
}

Automatic Barcode Gap Discovery (ABGD) (Puillandre et al., 2012) is based on computing the threshold distance or "barcoding gap" between inter- and intraspecific variation that leads toward the number of groups. In the present case ABGD analyses were performed with the default settings $(P \min =0.001, P \max =0.1$, Steps $=10, \mathrm{X}=1.5, \mathrm{Nb}$ bins $=20)$ on the ABGD website ${ }^{2}$ with JC69 Jukes-Cantor parameter. This parameter reflects the assumption that base frequencies are equal with one substitution rate (Emerson et al., 2001) and gave the clearest barcoding gap within all tested parameters for our data.

Another distance-based method is CD-HIT (Li and Godzik, 2006), a heuristic clustering process that requires defined sequence similarity thresholds. The CD-HIT-EST method was used on the CD-HIT Suite web server at the University of California, San Diego, ${ }^{3}$ and analyses were done with default settings and the predefined threshold of $97.6 \%$.

The third method of delimitation that used calculated distances is the Barcode Index Numbers (BINs) system implemented in BOLD (Ratnasingham and Hebert, 2013). It registers each cluster of sequences and assigns a unique and specific code (BIN). An uploaded sequence goes through cluster analyses that try to find discontinuities between the clusters.

In contrast, general mixed Yule coalescence is a method that determines the point of transition from speciation to coalescent branching patterns on an ultrametric tree (Pons et al., 2006; Monaghan et al., 2009). When this method was performed, a Bayesian inference tree was built with BEAST v1.8.3 (Drummond et al., 2012). Yule-coalescent models as implemented in the $\mathrm{R}$ package "splits" (Suchard et al., 2018) were used.

Moreover, another method determining the transition from speciation to coalescent branching, the Bayesian Poisson tree process for larger datasets (Zhang et al., 2013) was tested on the web server. ${ }^{4}$ As input file the Bayesian tree calculated by BEAST was used. The data were inserted as an unrooted tree, 100,000 MCMC generations, thinning of 100, and 0.1 burn-in.

For the graphic presentation of MOTUs and morphospecies, Bayesian tree analyses were conducted for the COI dataset. The

\footnotetext{
${ }^{2}$ https://bioinfo.mnhn.fr/abi/public/abgd/abgdweb.html

${ }^{3}$ http://weizhong-lab.ucsd.edu/cdhit-web-server/cgi-bin/index.cgi

${ }^{4}$ http://species.h-its.org/ptp/
} 
optimal model was identified by the modeltest carried out by MEGA X (Kumar et al., 2018) using both the Akaike Information Criterion (AIC) and the Bayesian Information Criterion (BIC). For the COI dataset the Tamura-Nei (TN93 + G + I) model was the best fitting model. For construction of the tree, the BEAST v1.8.3 package and Yule-coalescent model as implemented in the R package "splits" (Suchard et al., 2018) were applied. The tree was produced and annotated with Bayesian posterior probabilities (PP) with TreeAnnotator in the BEAST v1.8.3 package.

For inference of phylogenetic relationships among recorded species, 16S and 18S rDNA gene fragments from one to three representatives of recognized MOTUs were amplified and added to the COI dataset. The tree of concatenated sequences of all three markers studied (27 individuals) was generated by the software Mr. Bayes (Ronquist and Huelsenbeck, 2003) by means of 15,000,000 generations, 2 runs, 4 chains, and a burn-in of 4,000. Gaps in the alignment were treated as the nucleotide $\mathrm{N}$. Individual models were calculated for each marker: COI, General Time Reversible (GTR + G); 16S, Hasegawa-KishinoYano $(\mathrm{HKY}+\mathrm{G}+\mathrm{I})$; 18S, General Time Reversible $(\mathrm{GTR}+\mathrm{G})$. All trees were graphically adjusted with the software Adobe ${ }^{\circledR}$ Photoshop ${ }^{\circledR} 21.1 .3$.

\section{Community Analyses and Population Connectivity}

Rating the species richness was performed by generating the rarefaction curves (Hessler and Sanders, 1967). The individual rarefaction curve was processed by means of Past 4.05 (Hammer et al., 2001). In combination with the Venn diagram, it was adjusted in the software Adobe ${ }^{\circledR}$ Photoshop ${ }^{\circledR}$ 21.1.3.
For analysis of the population connectivity between the two locations, haplotype networks were generated by Population Analysis with Reticulate Trees (PopART). ${ }^{5}$ Minimum spanning network (Bandelt et al., 1999) was applied for all MOTUs of the COI dataset. The haplotypes of all MOTUs of the genus Paralicella are presented together to demonstrate the differences and similarities between the recognized molecular units. Furthermore, for the COI dataset statistical tests were carried out by means of DnaSP6 (Librado and Rozas, 2009; Rozas et al., 2017) and Arlequin 3.5 (Excoffier and Lischer, 2010) for estimation of the gene diversity. For all populations with sample size $n \geq 4$, haplotype (h) and nucleotide $(\pi)$ diversities (Tajima, 1983), Fu's Fs (Fu, 1996), and Tajima’s D (Tajima, 1989) were calculated.

Additional diversity analyses on the COI dataset were performed in Arlequin 3.5 (Excoffier and Lischer, 2010). To detect species population differentiation within and among predefined groups, we performed an AMOVA with 1,000 permutations and pairwise differences. Two groups were selected-"active" and "inactive"-from analysis of the COI sequences obtained.

\section{RESULTS}

\section{Species Delimitation and Identification}

Baited traps AT1 and AT2 captured 463 scavenging amphipods, which could be identified morphologically as 18 different morphospecies (Figures 2, 3) (AT1, 364 individuals; AT2, 99 individuals). Trap AT3 captured no amphipods. From 279 individuals used for molecular study, 258 high-quality sequences

\footnotetext{
${ }^{5}$ http://popart.otago.ac.nz
}

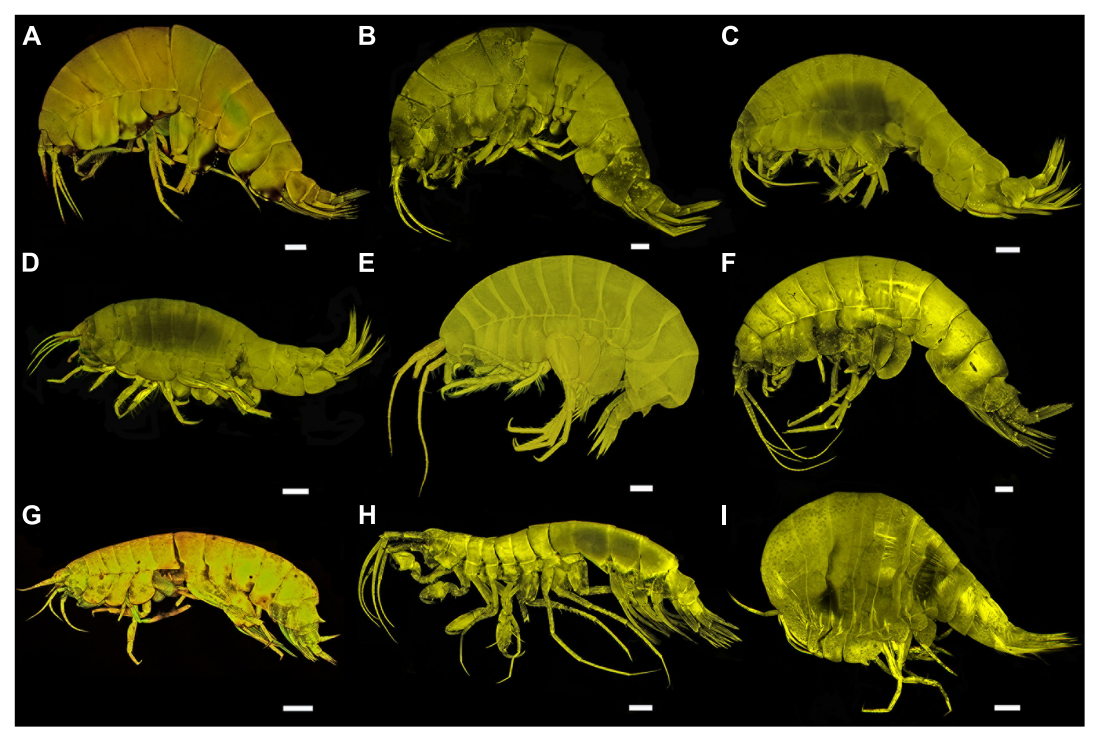

FIGURE 2 | Confocal images of all sampled taxa of Alicelloidea, Eusiroidea, and Stegocephaloidea. (A) Paralicella sp. group 1A DZMB_2021_0085. (B) Paralicella sp. group 1B DZMB_2021_0086. (C) Paralicella sp. group 2A DZMB_2021_0087. (D) Paralicella sp. group 2B DZMB_2021_0088. (E) Tectovalopsis aff. diabolus. (F) Tectovalopsis fusilus. (G) Valettiopsis sp. DZMB_2021_0091. (H) Cleonardo neuvillei. (I) Parandania sp. (E,G): scale = 500 $\mu$ m. (A-D,F,H,I): scale = 1 mm. 
of COI were obtained (PCR and sequencing success rate: $92.5 \%$ ) (Table 3) $(+21$ individuals not sequenced +184 individuals checked only morphologically). Fragment lengths ranged from 527 to $658 \mathrm{bp}$; no indels or stop codons were found.

The molecular species delimitation methods revealed 20 to 29 MOTUs (Table 3, Supplementary Figures 3-5, and Supplementary Tables 3-9). From all the methods combined, consensus clusters were created for conform results of at least three of them. The result in all cases was a consensus cluster except for the genus Paralicella. Within this genus two entities were identified on the basis of morphology-Paralicella sp. group 1 (presenting morphological similarity to Paralicella vaporalis Barnard and Ingram, 1990) and group 2 (showing some similarities with P. caperesca Barnard and Shulenberger, 1976)which were further divided by molecular study. Within the first all delimitation methods recognized two MOTUs, whereas in the second the number of molecular units ranged from three (ABGD, initial partition) to nine (general mixed Yule-coalescence and Bayesian Poisson tree process); in the second case four consensus MOTUs were defined. As a result, 24 MOTUs with 17 clusters and 7 singletons (Figure 4) were identified.

All recognized MOTUs were identified to genus level (from a combination of the morphological and molecular identification), and seven units were identified to species level (Table 3). For another three MOTUs, affinities with described species were found-Tectovalopsis aff. diabolus Barnard and Ingram, 1990, Paracallisoma aff. alberti Chevreux, 1903, and Pseudonesimus aff. abyssi Chevreux, 1926-whereas, four more recognized units are probably new to science-Eurythenes sp. DISCOLL PAP B, Hirondellea sp. nov. DZMB_2021_0092, Ambasiopsis sp. nov. DZMB_2021_0093, and Paracallisoma sp. nov. DZMB_2021_0094.

In addition to the COI dataset, 54 sequences of 16S (PCR and sequencing success rate: $81.8 \%$ ) and 44 sequences of $18 \mathrm{~S}$ (PCR and sequencing success rate: 66.7\%) were obtained (Table 3). The phylogenetic tree containing 27 concatenated sequences represents 16 MOTUs within 4 superfamilies (Figure 5). The tree supports the separation of Lysianassoidea and Alicelloidea. Within Lysianassoidea, representatives of different families were grouped together. A different situation can be seen in the case of Alicelloidea, where representatives of two families (Valettiopsidae and Alicellidae) were mixed. The species Tectovalopsis aff. diabolus and Paralicella sp. group 1 formed one cluster with Valettiopsis sp. DZMB_2021_0091, whereas the Paralicella group 2 was clearly separated with high posterior probabilities.

\section{Faunistic Composition and Population Connectivity}

The 364 individuals collected by trap AT1 at the inactive field formed 19 MOTUs in 11 genera (Figure 6A). The 99 captured by trap AT2 at the active field, belonged to 10 MOTUs and five genera. Trap AT3, placed for $22 \mathrm{~h}$ close to an active field, captured no amphipods. Only seven MOTUs were captured at both AT1 and AT2. The calculations of the rarefaction curves indicated higher species richness at inactive fields; for active fields the curve approached asymptote and flattens out (Figure 6B).
The amphipod assemblage of the inactive site was dominated by Tectovalopsis fusilus and Hirondellea guyoti, which constituted $60.4 \%$ of all individuals collected (Figure 7). The remaining 17 MOTUs were represented by similar numbers of individuals. The dominating taxon at the active site was Paralicella sp. group 2B DZMB_2021_0088, which alone made up more than 50\% of abundance. The other taxa contributing substantially to this assemblage were Abyssorchomene distinctus, Hirondellea sp. nov. DZMB_2021_0092, Paracallisoma sp. nov. DZMB_2021_0094, and Paralicella sp. group 1B DZMB_2021_0086. The genera Eurythenes and Tectovalopsis were collected exclusively at the inactive site.

In the whole area studied, three taxa (Cleonardo neuvillei, Ambasiopsis sp. nov. DZMB_2021_0093, and Parandania sp.) were each represented by a single individual (Figure 8A). Among the remaining species, haplotype numbers ranged from 1 to 30 (Table 4).

The haplotype diversity (h) was high for AT1 and for the combined data of AT1 and AT2 in Paralicella sp. group 2B DZMB_2021_0088 $(h=0.800-0.835)$, Eurythenes sp. DISCOLL PAP B $(h=0.857)$, Hirondellea guyoti $(h=0.709)$, and Hirondellea sp. nov DZMB_2021_0092 $(h=0.782,0.833)$, whereas for Paracallisoma aff. alberti $(h=1.000)$ only AT1 and, for Abyssorchomene distinctus ( $h=0.928-0.952)$, the whole set of data showed high haplotype diversity. Nucleotide diversity $(\pi)$ was low for all populations, ranging between $\pi=0.00047$ for Paracallisoma sp. nov. DZMB_2021_0094 (combined data) and $\pi=0.00674$ for Eurythenes sp. DISCOLL PAP B (Table 4).

The haplotype network for the genus Paralicella (Figure 8B) indicated a clear separation between the six MOTUs, with a mutation rate of 29 to 103 substitutions. The three individuals constituting MOTU Paralicella sp. group 2A DZMB_2021_0087 showed 24 and 27 substitutions among its representatives.

The neutrality and population-expansion tests revealed that, for the populations of Paralicella sp. group $2 \mathrm{~B}$ DZMB_2021_0088, Tectovalopsis fusilus, and Abyssorchomene distinctus, the Tajima's $\mathrm{D}$ values were negative and significant $(p<0.05)$, indicating an excess of rare nucleotides thus an expansion of the population or indicative of a selective sweep. Fu's Fs confirmed this theory with negative values and highly significant $p$-values $(p<0.001-0.0001)$. Similarly, evidence for expansion of populations was observed in Hirondellea sp. nov. DZMB_2021_0092, Paracallisoma aff. alberti, and Paracallisoma sp. nov. DZMB_2021_0094. The values for Tajima's $\mathrm{D}$ and Fu's Fs combined with mainly significant $p$-values (Table 4).

Within-population differences in the analysis of molecular variance (AMOVA) accounted for all the variation (100\%) for most of the species, and no evidence supported separation into genetically distinct populations (Table 5). In addition, negative or near-zero Fst-values indicated that the studied populations were genetically homogeneous, but all $p$-values were not significant, indicating no population structure. The only exception was Abyssochormene distinctus, where the variation of the AMOVA within the population was $95.39 \%$ and the Fst was positive, but $p$-values were still not significant, indicating no population structure. 
TABLE 3 | The list of taxa identified, with superfamily, family and genus information, number of sequences for COI, 16S, and 18S, morphological delimitation (M), number of MOTUs based on Automatic Barcode Gap Discovery (Ai, initial, and Ar, recursive, partition), CD-Hit (C), GMYC (G), bPTP (B), and BIN.

\begin{tabular}{|c|c|c|c|c|c|c|c|c|c|c|c|c|c|c|c|c|}
\hline \multirow[t]{2}{*}{ Superfamily } & \multirow[t]{2}{*}{ Family } & \multirow[t]{2}{*}{ Genus } & \multirow[t]{2}{*}{ Species } & \multicolumn{2}{|c|}{ No. individuals } & \multicolumn{3}{|c|}{ Marker } & \multicolumn{7}{|c|}{ Species delimitation methods } & \multirow[t]{2}{*}{ BOLD BIN } \\
\hline & & & & AT1 & AT2 & $\mathrm{CO}$ & $16 S$ & $18 S$ & $\mathbf{M}$ & $\mathbf{A i}$ & $\mathrm{Ar}$ & c & G & B & BIN & \\
\hline \multirow[t]{9}{*}{ Alicelloidea } & Alicellidae & Paralicella Chevreux, 1908 & $\begin{array}{l}\text { Paralicella sp. group 1A } \\
\text { DZMB_2021_0085 }\end{array}$ & 2 & 3 & 5 & 2 & 3 & 1 & 1 & 1 & 1 & 1 & 1 & 1 & BOLD:AEF8804 \\
\hline & & & $\begin{array}{l}\text { Paralicella sp. group 1B } \\
\text { DZMB_2021_0086 }\end{array}$ & 0 & 6 & 6 & 1 & 2 & 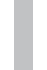 & 1 & 1 & 1 & 1 & 1 & 1 & BOLD:AEF6691 \\
\hline & & & $\begin{array}{l}\text { Paralicella sp. group 2A } \\
\text { DZMB_2021_0087 }\end{array}$ & 0 & 3 & 3 & 3 & 2 & 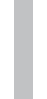 & 1 & 1 & 3 & 3 & 3 & 3 & $\begin{array}{l}\text { BOLD:AEF9380 } \\
\text { BOLD:AEF9381 } \\
\text { BOLD:AEF9383 }\end{array}$ \\
\hline & & & $\begin{array}{l}\text { Paralicella sp. group 2B } \\
\text { DZMB_2021_0088 }\end{array}$ & 16 & 54 & 63 & 10 & 6 & 1 & 1 & 1 & 1 & 3 & 4 & 1 & BOLD:AEF6635 \\
\hline & & & $\begin{array}{l}\text { Paralicella sp. group 2C } \\
\text { DZMB_2021_0089 }\end{array}$ & 2 & 1 & 3 & 1 & 0 & 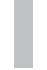 & 1 & 1 & 1 & 2 & 2 & 1 & BOLD:AEF6636 \\
\hline & & & $\begin{array}{l}\text { Paralicella sp. group 2D } \\
\text { DZMB_2021_0090 }\end{array}$ & 1 & 0 & 1 & 1 & 1 & 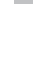 & 1 & 1 & 1 & 1 & 1 & 1 & BOLD:AEF9382 \\
\hline & & $\begin{array}{l}\text { Tectovalopsis Barnard and Ingram, } \\
1990\end{array}$ & $\begin{array}{l}\text { Tectovalopsis aff. diabolus } \\
\text { Barnard and Ingram, } 1990\end{array}$ & 3 & 0 & 3 & 3 & 3 & 1 & 1 & 1 & 1 & 1 & 1 & 1 & BOLD:AEF9480 \\
\hline & & & $\begin{array}{l}\text { Tectovalopsis fusilus Barnard and } \\
\text { Ingram, } 1990\end{array}$ & 131 & 0 & 78 & 2 & 2 & 1 & 1 & 1 & 1 & 1 & 1 & 1 & BOLD:AEF6344 \\
\hline & Valettiopsidae & Valettiopsis Holmes, 1908 & $\begin{array}{l}\text { Valettiopsis sp. } \\
\text { DZMB_2021_0091 }\end{array}$ & 2 & 0 & 1 & 2 & 2 & 1 & 1 & 1 & 1 & 1 & 1 & 1 & BOLD:AEF7847 \\
\hline Eusiroidea & Eusiridae & Cleonardo Stebbing, 1888 & $\begin{array}{l}\text { Cleonardo neuvillei Chevreux, } \\
1908\end{array}$ & 1 & 0 & 1 & 1 & 1 & 1 & 1 & 1 & 1 & 1 & 1 & 1 & BOLD:AEF6468 \\
\hline \multirow[t]{11}{*}{ Lysianassoidea } & Eurytheneidae & $\begin{array}{l}\text { Eurythenes S. I. Smith in Scudder, } \\
1882\end{array}$ & $\begin{array}{l}\text { Eurythenes magellanicus (H. Milne } \\
\text { Edwards, 1848) }\end{array}$ & 9 & 0 & 8 & 2 & 3 & 1 & 1 & 1 & 1 & 1 & 1 & 1 & BOLD:ADD1766 \\
\hline & & & Eurythenes sp. DISCOLL PAP B & 8 & 0 & 7 & 1 & 2 & 1 & 1 & 1 & 1 & 1 & 2 & 1 & BOLD:AEF7086 \\
\hline & Hirondelleidae & Hirondellea Chevreux, 1889 & $\begin{array}{l}\text { Hirondellea brevicaudata } \\
\text { Chevreux, } 1910\end{array}$ & 6 & 0 & 5 & 3 & 2 & 1 & 1 & 1 & 1 & 1 & 1 & 1 & BOLD:AEF6862 \\
\hline & & & $\begin{array}{l}\text { Hirondellea guyoti Barnard and } \\
\text { Ingram, } 1990\end{array}$ & 89 & 0 & 11 & 1 & 2 & 1 & 1 & 1 & 1 & 1 & 1 & 1 & BOLD:AEF7644 \\
\hline & & & $\begin{array}{l}\text { Hirondellea sp. nov. } \\
\text { DZMB_2021_0092 }\end{array}$ & 22 & 11 & 13 & 2 & 1 & 1 & 1 & 1 & 1 & 1 & 1 & 1 & BOLD:AEF9394 \\
\hline & $\begin{array}{l}\text { Lysianassoidea } \\
\text { incertae sedis }\end{array}$ & Ambasiopsis K.H. Barnard, 1931 & $\begin{array}{l}\text { Ambasiopsis sp. nov. } \\
\text { DZMB_2021_0093 }\end{array}$ & 1 & 0 & 0 & 1 & 1 & 1 & - & - & - & - & - & - & - \\
\hline & Scopelocheiridae & $\begin{array}{l}\text { Haptocallisoma Horton and Thurston, } \\
2015\end{array}$ & $\begin{array}{l}\text { Haptocallisoma abyssi (Oldevig, } \\
\text { 1959) }\end{array}$ & 0 & 3 & 3 & 3 & 0 & 1 & 1 & 1 & 1 & 1 & 1 & 1 & BOLD:ADH7303 \\
\hline & & Paracallisoma Chevreux, 1903 & $\begin{array}{l}\text { Paracallisoma aff. alberti } \\
\text { Chevreux, } 1903\end{array}$ & 10 & 2 & 9 & 4 & 3 & 1 & 1 & 1 & 1 & 2 & 2 & 2 & $\begin{array}{l}\text { BOLD:AEF7929 } \\
\text { BOLD:AEF9456 }\end{array}$ \\
\hline & & & $\begin{array}{l}\text { Paracallisoma sp. nov. } \\
\text { DZMB_2021_0094 }\end{array}$ & 18 & 9 & 13 & 2 & 1 & 1 & 1 & 1 & 1 & 1 & 1 & 1 & BOLD:AEF8324 \\
\hline & Tryphosidae & Pseudonesimus Chevreux, 1926 & $\begin{array}{l}\text { Pseudonesimus aff. abyssi } \\
\text { Chevreux, } 1926\end{array}$ & 23 & 0 & 6 & 3 & 3 & 1 & 1 & 1 & 1 & 1 & 1 & 1 & BOLD:AEF6700 \\
\hline & Uristidae & Abyssorchomene De Broyer, 1984 & $\begin{array}{l}\text { Abyssorchomene distinctus } \\
\text { (Birstein and Vinogradov, 1960) }\end{array}$ & 19 & 7 & 18 & 5 & 4 & 1 & 1 & 1 & 1 & 1 & 1 & 1 & BOLD:ACZ6415 \\
\hline Stegocephaloidea & Stegocephalidae & Parandania Stebbing, 1888 & Parandania sp. & 1 & 0 & 1 & 1 & 1 & 1 & 1 & 1 & 1 & 1 & 1 & 1 & BOLD:AAF7953 \\
\hline Total numbers & 10 & 12 & 22 & 364 & 99 & 258 & 54 & 45 & 18 & 20 & 21 & 23 & 27 & 29 & 24 & \\
\hline
\end{tabular}

Last column provides the BIN code. Shading indicate cases where incongruence between different delimitation methods was noted. 


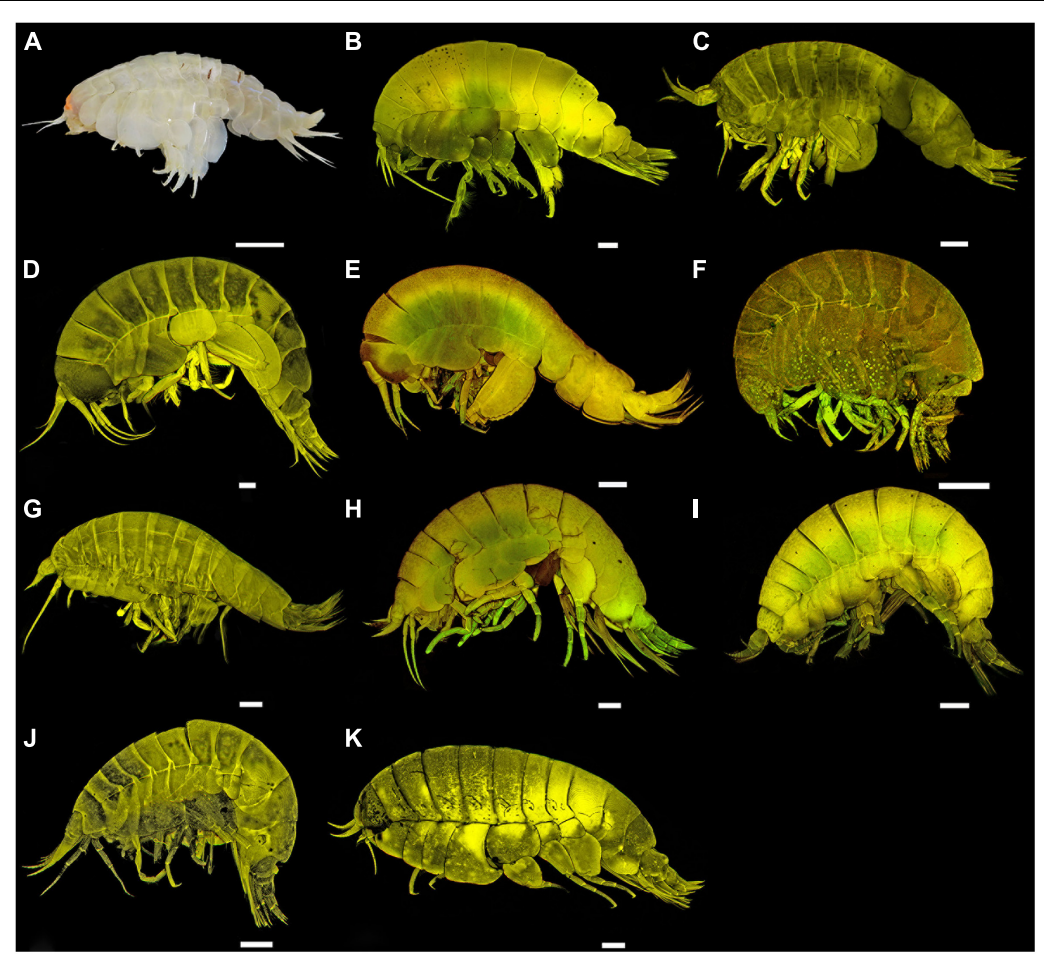

FIGURE 3 | Confocal images of all sampled taxa of Lysianassoidea (including one light microscopy image of a large species, A). (A) Eurythenes magellanicus. (B) Eurythenes sp. DISCOLL PAP B. (C) Hirondellea brevicaudata. (D) Hirondellea guyoti. (E) Hirondellea sp. nov. DZMB_2021_0092. (F) Ambasiopsis sp. nov DZMB_2021_0093. (G) Haptocallisoma abyssi. (H) Paracallisoma aff. alberti. (I) Paracallisoma sp. nov. DZMB_2021_0094. (J) Pseudonesimus aff. abyssi. (K) Abyssorchomene distinctus. (A): scale $=2 \mathrm{~cm}$. (B,K): scale $=1 \mathrm{~mm}$. (C-J): scale $=500 \mu \mathrm{m}$.

\section{DISCUSSION}

\section{Morphological vs. Molecular Identification of Amphipods}

Studying baited-trap samples from hydrothermal vent areas by morphological methods supplemented by DNA barcoding led us to a total of 22 MOTUs belonging to 10 genera and four families. For the MOTUs collected, the morphology agreed with the molecular species delimitation, except for the genus Paralicella.

Paralicella includes six described species so far (WoRMS Editorial Board, 2021), but taxonomic issues have been mentioned for this genus. Ritchie et al. (2015) reported incongruence between the morphological and molecular identifications of two species within this genus but the discrepancies were not confirmed later (Mohrbeck et al., 2021). In contrast, high mean intraspecific divergences were reported for Paralicella caperesca (Jażdżewska et al., 2021; Mohrbeck et al., 2021). Our morphological study of the representatives of Paralicella separated them into two different groups, but they were further divided into molecular clades with non-distinct external appearance.

Additional morphological study is required to confirm that these taxa should be treated as cryptic species or to find the morphological characters that will allow separation of the MOTUs within these species complexes. Moreover, individuals within one MOTU of Paralicella sp. group 2 (group 2A DZMB_2021_0087) showed high COI sequence divergence (expressed among other evidence by ascription of three different BINs) that may reflect, for example, past population divergence and then subsequent introgression. Because only fragments of two mitochondrial and one nuclear gene loci were sequenced, definite delineation of species within these MOTUs is not possible-ideally data from more than one nuclear gene loci should be obtained.

\section{Scavenging Community in the Studied Area}

The known distribution of the taxa collected is shown in Table 6. Abyssorchomene distinctus is the only species in our collection that was previously detected in the Indian Ocean. Apart from Cleonardo neuvillei, all taxa recorded in the present study were previously caught with baited traps. Cleonardo species are considered bathypelagic and carnivorous (Bousfield and Hendrycks, 1995), so the presence of single individual in our samples can be regarded as a by-catch.

The genus Eurythenes is very commonly collected with baited traps (Jamieson et al., 2011; Havermans et al., 2013; NaraharaNakano et al., 2018). Of Eurythenes magellanicus, we detected the largest individual $(105 \mathrm{~mm})$ reported so far that was still an immature female. The largest previously named representative for that species is a mature female $85 \mathrm{~mm}$ collected from the 


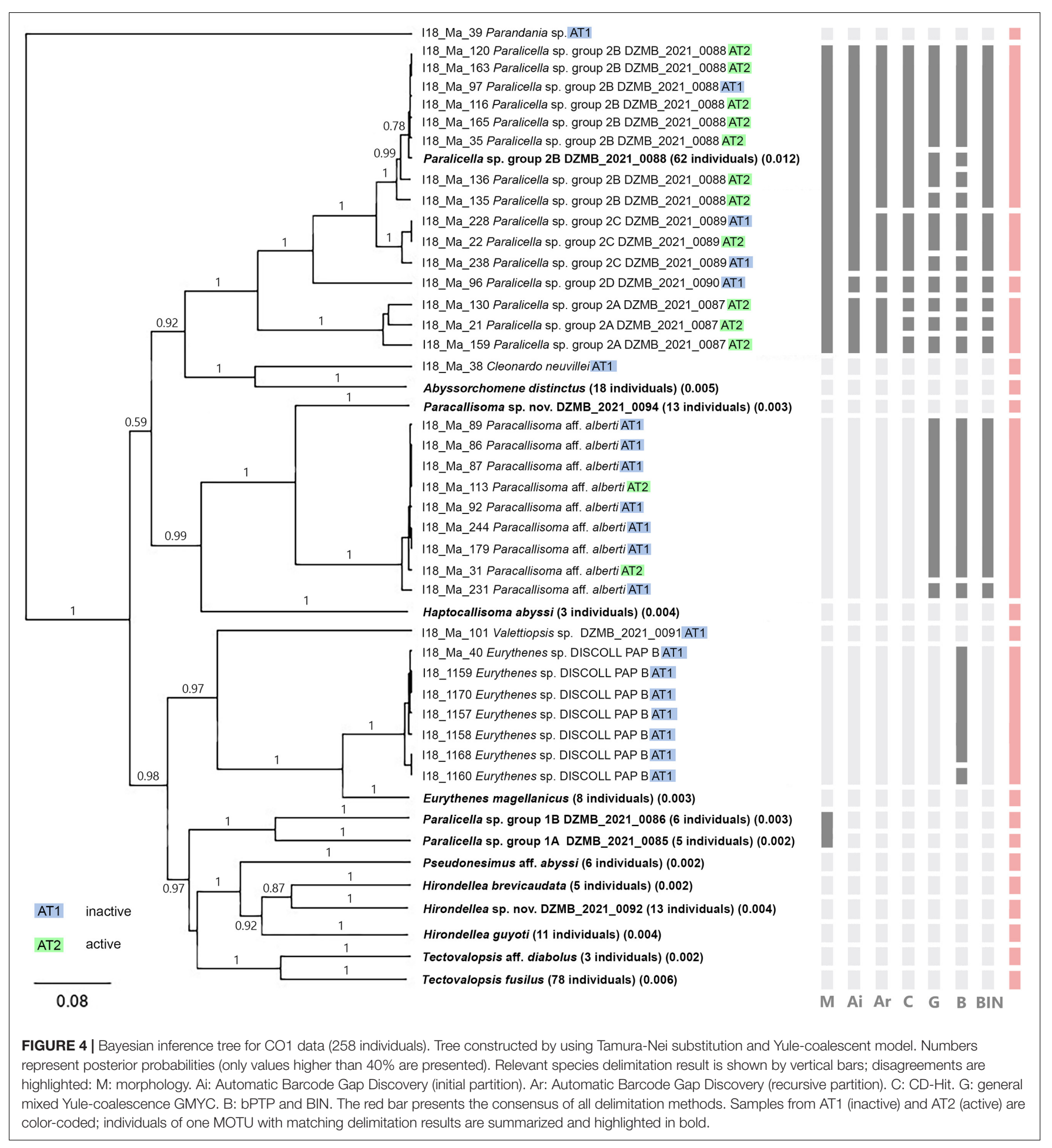

stomach of a fish off Cape Horn (Stoddart and Lowry, 2004). The deep-sea species belonging to the genus Hirondellea are commonly found in baited traps (Jamieson et al., 2011; Ritchie et al., 2015; Duffy et al., 2016) as well as at hydrothermal vent fields (Barnard and Ingram, 1990). Ambasiopsis, another genus belonging to Lysianassoidea, has been recorded from the Indian Ocean before, and it was represented by Ambasiopsis brevipes
Ledoyer, 1986 collected at Banc du Geyser (Ledoyer, 1986). A detailed check of our Ambasiopsis material revealed, however, that it is a different species.

Some species from the superfamily Alicelloidea were collected as well. The genus Paralicella is known from all three oceans, including Antarctic waters (Chevreux, 1908; Shulenberger and Barnard, 1976; De Broyer et al., 2004; Horton and Thurston, 


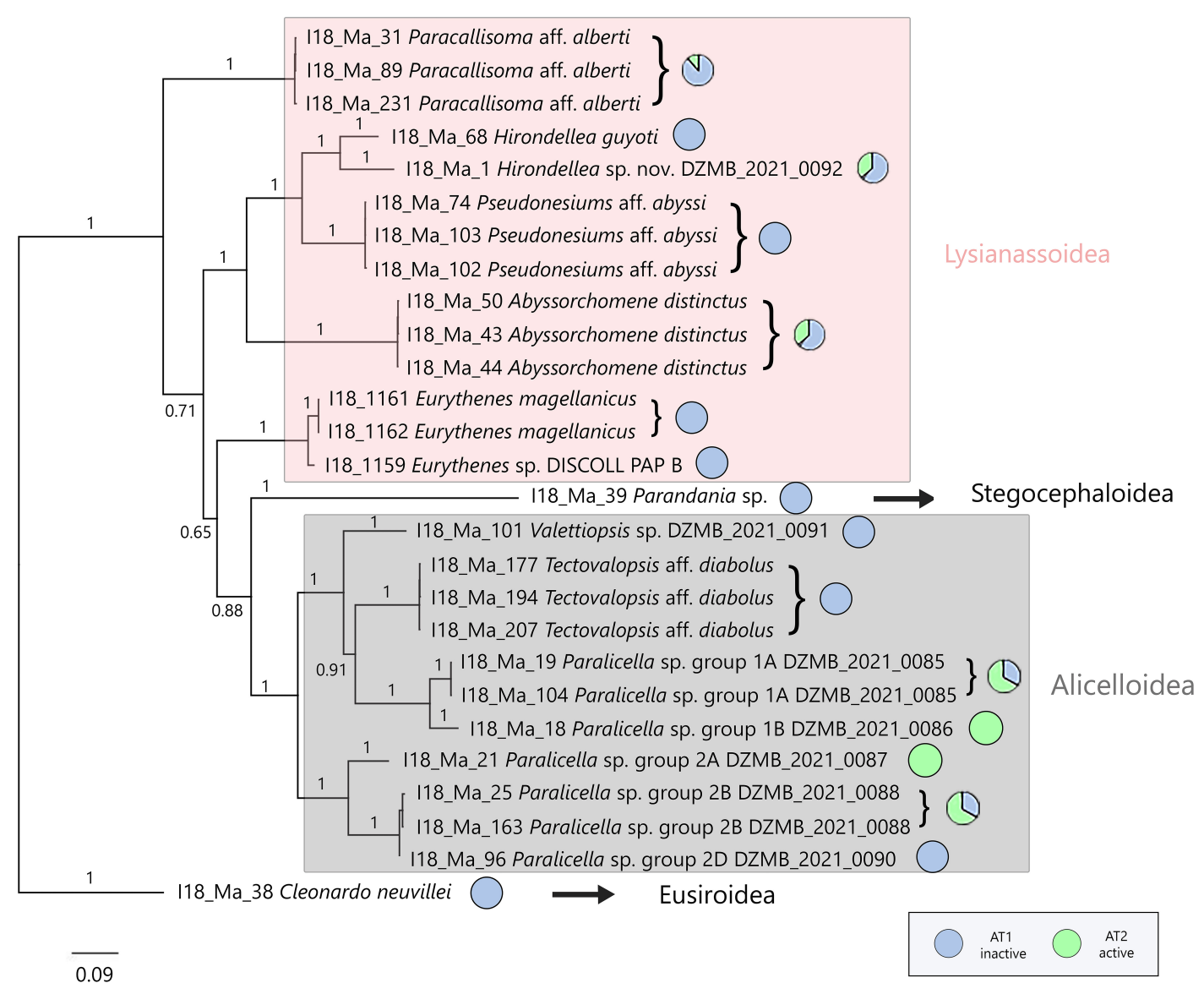

FIGURE 5 | Bayesian inference tree construction on the concatenate three-gene dataset (COI, 16S rDNA, 18S rDNA). The distances were calculated with the General Time Reversible model (COI, 18S) and the Hasegawa-Kishino-Yano model (16S). Numbers represent posterior probabilities. Next to the tree information about the relative abundances for the two locations are given. The superfamilies are indicated on the right.

2009; Horton et al., 2020b; Weston et al., 2021; Jażdżewska et al., 2021) and has been collected at hydrothermal vent fields before (Barnard and Ingram, 1990), as has Valettiopsis (Juan de Fuca Ridge in the Pacific Ocean) (Tsurumi, 2001). The genus Parandania is not only a worldwide distributed genus, but was also sampled at hydrothermal vents (Wang et al., 2019). One species within this genus, Parandania boecki is panoceanic and reported from Indian Ocean (De Broyer et al., 2007).

\section{Population Connectivity and Community Analyses}

Our study provides the first known records for scavenging amphipods caught with the help of baited traps at hydrothermal vent fields in the Indian Ocean. Nevertheless, sampling in the deep sea is sometimes challenging, and certain limitations to the study must be mentioned. The first is lack of replicates, second that the active and inactive sites are some distance apart and without adjacent non-vent abyssal controls, and third that the traps were left on the sea floor for different periods of time (Table 1). These factors might produce differences within the species composition and abundance. Similarly, differences in abiotic factors at the three traps locations might influence the fauna that approached them.

The distribution of organic matter and the hydrostatic pressure are important in defining the composition of hadal scavenging communities (Wolff, 1959; Beliaev and Brueggeman, 1989). Experimental study has revealed that some amphipod species are not flexible enough to colonize highly disturbed zones, for example glacier melting areas or bottom sections opened after ice shelf collapse because of changes in salinity and intensive sedimentation (Seefeldt et al., 2017). Hydrothermally active areas can also be considered disturbed areas, with irregular abiotic factors like bursting chimneys, hypoxia (Hourdez and Lallier, 2007), high temperatures (Chevaldonné et al., 1991, 1992), and high levels of hydrogen sulfide, methane, ammonia, and heavy metals (Campbell et al., 1988a,b). In comparison, inactive areas offer stable environmental conditions that are more attractive to general deep-sea organisms (Erickson et al., 2009; Levin et al., 2009; Boschen et al., 2016). Similar values of temperature, salinity and $\mathrm{pH}$ were observed at all three locations, so these factors cannot explain the complete failure of trap AT3 even though it spent similar time on the bottom as the very successful AT1 trap. Of the three sites AT3 


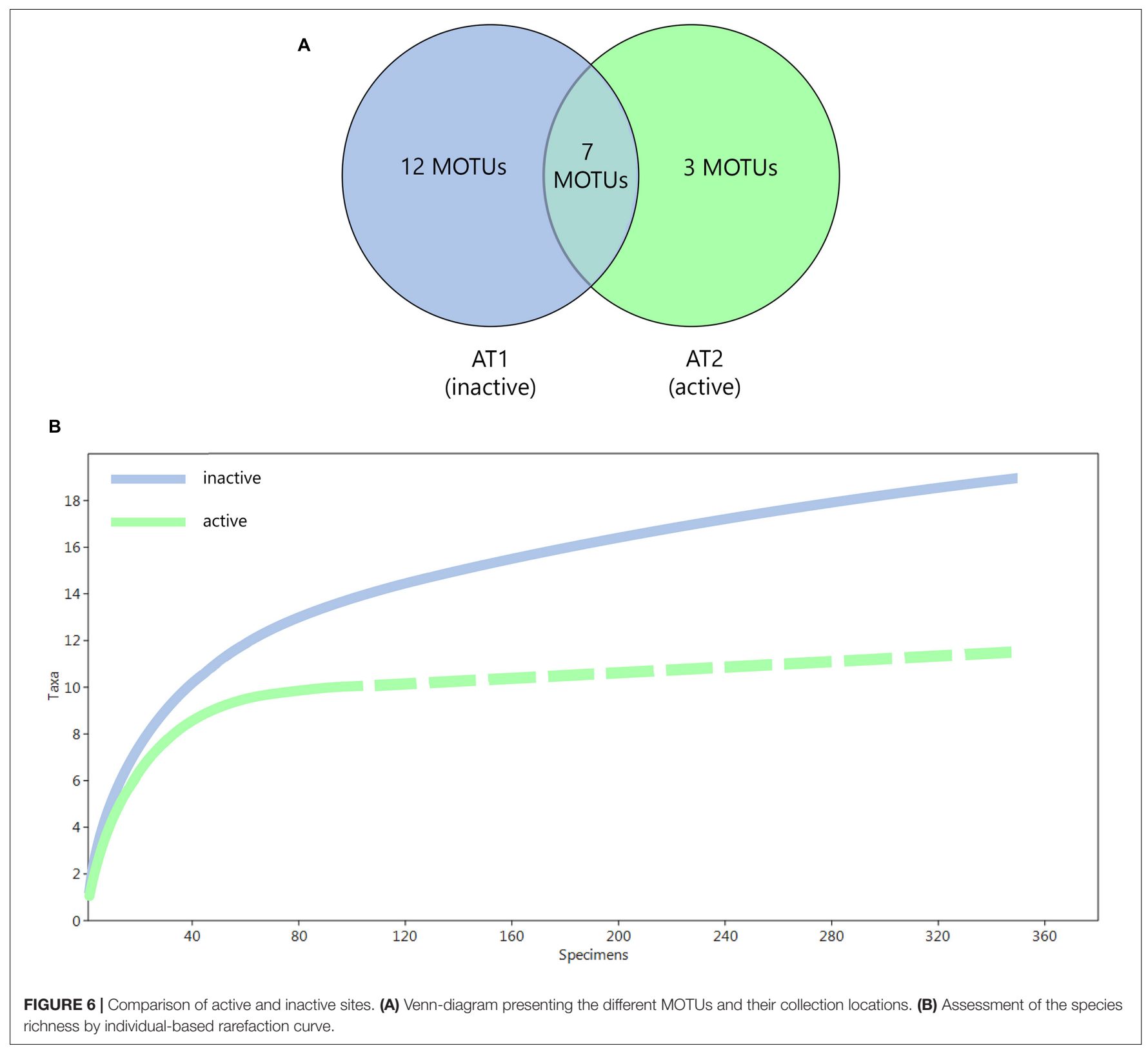

was situated in the closest vicinity of the active vent. The emissions from vents are associated with oxygen depletion in the surrounding waters (Hourdez and Lallier, 2007) while amphipods are regarded as having low tolerance to hypoxia (Modig and Ólafsson, 1998; Wu and Or, 2005; CopilaşCiocianu et al., 2020) that may caused their absence there. Unfortunately, the oxygen concentration data are not available for the studied sites, so this issue must remain open question. At the other two traps 463 amphipods were captured, but are these amphipods only occasional visitors to the fields or might they be vent endemic?

At hydrothermal vent fields life depends on the presence of chemoautotrophic microbes. In the Indian Ocean, the microbes support the high abundance of the shrimp Rimicaris kairei
Watabe and Hashimoto, 2002, which in turn sustains a variety of other vent endemic taxa, including fish species (Gerdes et al., 2021; Thiel et al., 2021). Generally, vent endemic species occur in high abundance around the active fields (Ingole and Koslow, 2005; Thornton et al., 2016), but despite the special food source, typical vent-endemic amphipods have not previously been reported from the Indian Ocean, even though knowledge about the vent fields along the Central and Southeast Indian Ridges has increased during the last decade as a result of the massive sulfide exploration program in the German license area (Gerdes et al., 2019a,b, 2021). The absence up to now of any amphipod records and abundance that is on average lower than those reported in the literature for baited traps (Duffy et al., 2012; Horton et al., 2020b; Patel et al., 2020), we conclude that the presently 


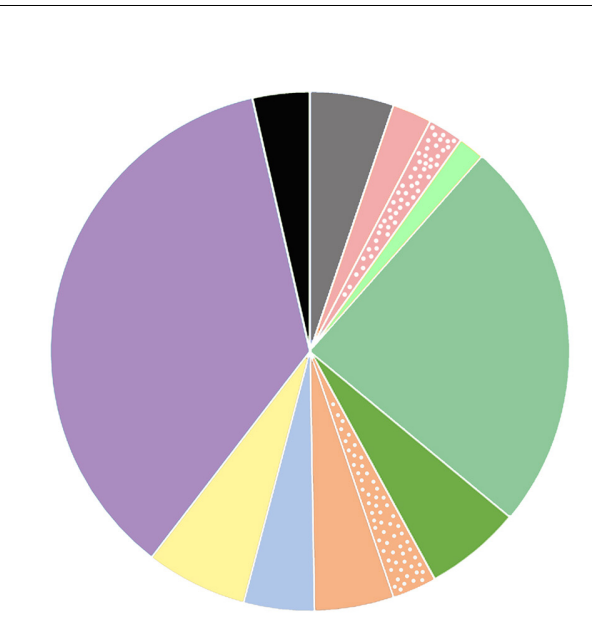

AT1 (inactive)

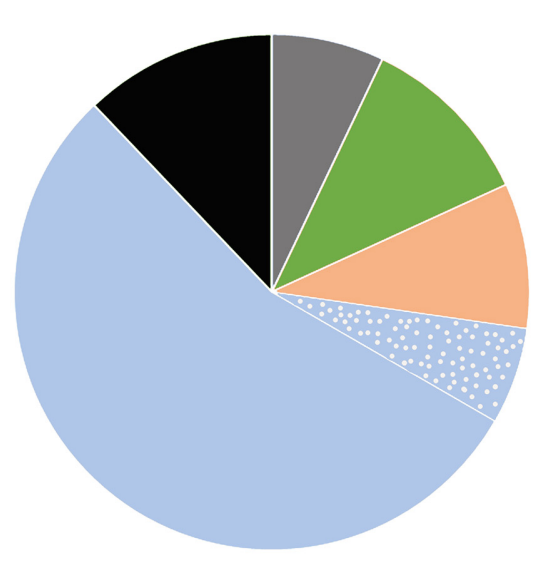

AT2 (active)

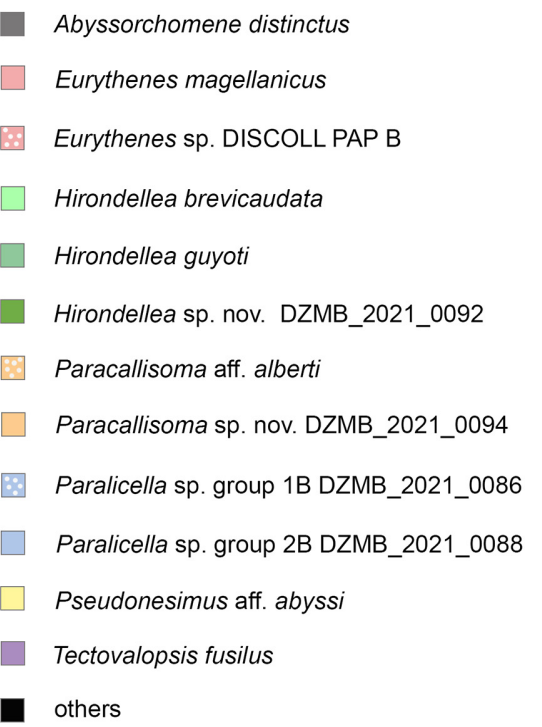

Abyssorchomene distinctus

Eurythenes sp. DISCOLLPAP

Hirondellea sp. nov. DZMB_2021_0092

FIGURE 7 | Relative abundance of MOTUs at the active and inactive areas. Unnamed MOTUs with $n \leq 3$ are grouped together as "others." More details about numbers of each MOTU can be found in Table $\mathbf{3}$

studied scavenging amphipod assemblage is probably not vent endemic. The three previously described species (Hirondellea guyoti, Tectovalopsis fusilus, and T. aff. diabolus) have so far been recorded exclusively from hydrothermal vent fields (Barnard and Ingram, 1990; Desbruyères et al., 2006), however, and we report four species new to science that have not yet been collected elsewhere. These species do not depend directly on the chemoautotrophic bacteria and primary production in the vent fields, but they may be more resistant to hypoxic conditions than other deep-sea amphipod species and may profit from the primary production that is offered by the vent fields. They may therefore be treated as vent related, but because no baited traps were set in the abyssal plain adjacent to the presently studied area, the presence of these species also outside the hydrothermal vent fields cannot be excluded.

Differences in amphipod assemblages between hydrothermally active and inactive regions can be observed. The inactive site was characterized by higher abundance and species richness (Table 3 and Figures 6, 7) than the active area. Rarefaction results indicated that the higher diversity at the inactive site would still be the expected result. In addition, the population analyses indicate a significant population expansion of the Paralicella sp. group 2B DZMB_2021_0088, Tectovalopsis fusilus, and Abyssorchomene distinctus (Table 5); the other species studied also tended to expand. Expanding populations are a general deep-sea phenomenon particularly in vent-endemic species (Vrijenhoek, 2010; Taylor and Roterman, 2017). Furthermore, the analyses of Tajima's D and Fu's Fs did not reveal clear differences within genetic diversity between populations at active and inactive sites. In addition, AMOVA reinforced this statement by comparing the mitochondrial COI sequences of active and inactive populations for six species from the Southeast Indian Ridge, resulting in a lack of genetic structure, as suggested by negative or non-significant values for Fst. On this basis, we speculate that no "active" or "inactive" vent communities are present. Instead, just one population probably approaches the different fields. The expansion of the populations in the deep sea may be associated with recent bottlenecks, dispersal of random individuals between patchy habitats, or positive selection (Taylor and Roterman, 2017) and, however, signify a large population size.

Different feeding strategies might explain the difference between the traps from active and inactive vents. These differences are not only quantitative (although the quantitative difference should be viewed with caution) but also qualitative, because the active area was dominated by Paralicella sp. group 2B DZMB_2021_0088. This genus is known to consist of obligate scavengers (Horton et al., 2020b) that are very successful in locating baits in the deep sea and depend only on this specific kind of food. Horton et al. (2020b) revealed that temporal changes in environmental conditions in the ocean may influence the scavenger community. These changes are reflected in the switch from obligate necrophagous amphipod dominance (Paralicella) to a more diverse assemblage with larger numbers of facultative scavengers (Abyssorchomene sp., Eurythenes spp.). In the present case, the differences in environmental conditions between the active and inactive sites may reflect the temporal changes observed by Horton et al. (2020b). These authors have also observed that the scavenger community changes with the time the bait spends on the bottom, from the dominance of obligate scavengers, to a more diverse assemblage with a higher share of facultative scavengers (Janßen et al., 2000). In our study the trap at the active site spend a shorter amount of time on the bottom, a difference that might have prevented less specialized amphipod species from reaching it, but the rarefaction curve for the active site sample 


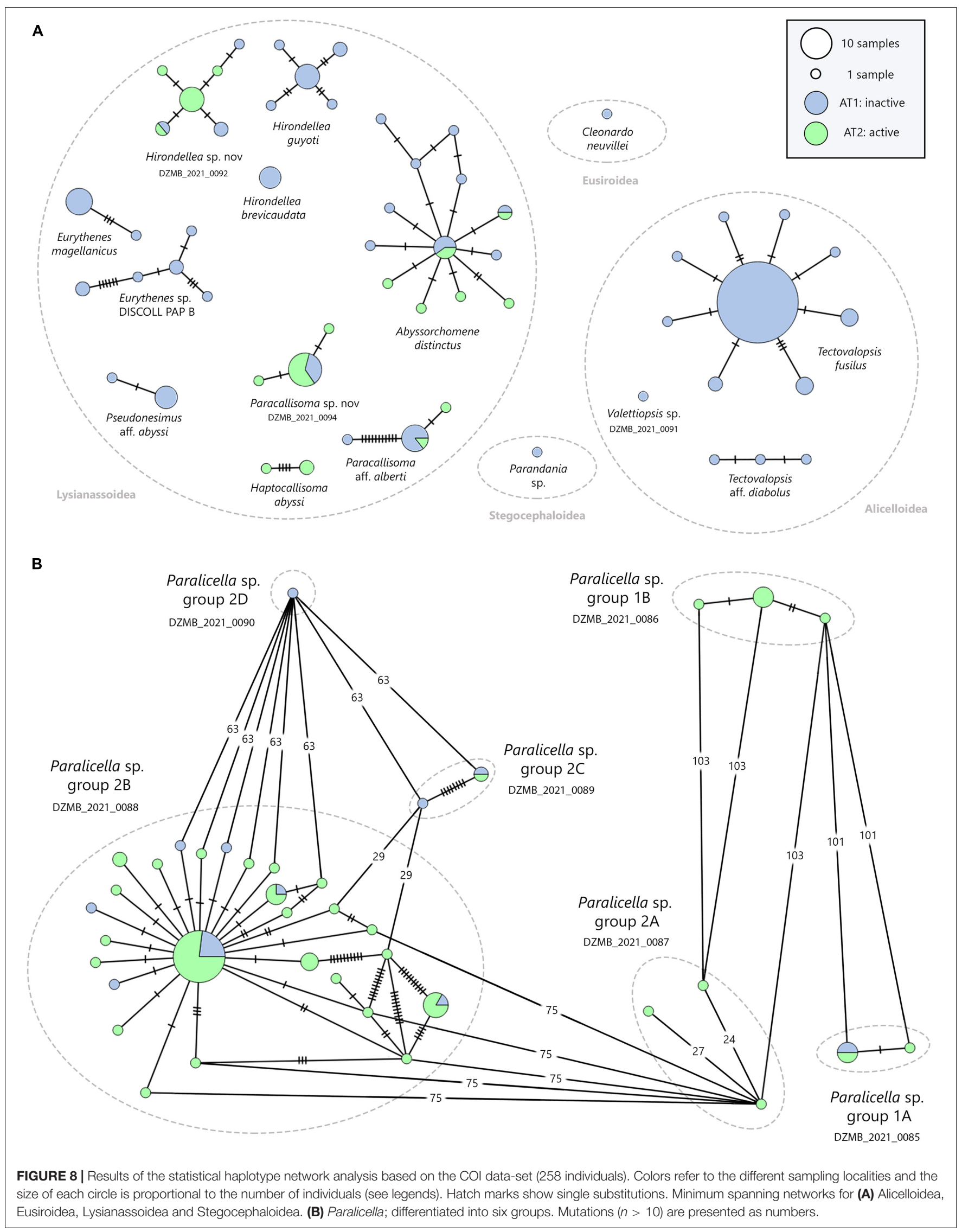


TABLE 4 | Genetic diversity indices, parameters of demographic history and neutrality and population expansion tests calculated for the COI dataset.

\begin{tabular}{|c|c|c|c|c|c|c|c|}
\hline Species & & $\mathbf{n}$ & $\begin{array}{c}\text { No. } \\
\text { haplotypes }\end{array}$ & $\begin{array}{l}\text { Haplotype } \\
\text { diversity (h) }\end{array}$ & $\begin{array}{l}\text { Nucleotide } \\
\text { diversity }(\pi)\end{array}$ & Tajima's D & Fu's Fs \\
\hline \multirow{3}{*}{$\begin{array}{l}\text { Paralicella sp. group 1A } \\
\text { DZMB_2021_0085 }\end{array}$} & AT1 & 2 & 1 & - & - & - & - \\
\hline & AT2 & 3 & 2 & 0.667 & 0.00101 & - & 0.20067 \\
\hline & com & 5 & 2 & 0.400 & 0.00061 & -0.81650 & 0.09021 \\
\hline $\begin{array}{l}\text { Paralicella sp. group 1B } \\
\text { DZMB_2021_0086 }\end{array}$ & AT2 & 6 & 3 & 0.600 & 0.00203 & -1.29503 & 0.29690 \\
\hline \multirow{3}{*}{$\begin{array}{l}\text { Paralicella sp. group 2B } \\
\text { DZMB_2021_0088 }\end{array}$} & AT1 & 15 & 9 & 0.800 & 0.00377 & $-1.95478^{*}$ & -2.10318 \\
\hline & AT2 & 53 & 23 & 0.835 & 0.00560 & $-1.95004^{\star}$ & $-16.22493^{\star \star \star}$ \\
\hline & com & 68 & 30 & 0.823 & 0.00510 & $-2.05811^{\star}$ & $-22.31432^{\star \star \star}$ \\
\hline Tectovalopsis fusilus & AT1 & 78 & 9 & 0.305 & 0.00077 & $-2.09503^{\star}$ & $-7.04595^{\star \star \star}$ \\
\hline $\begin{array}{l}\text { Eurythenes } \\
\text { magellanicus }\end{array}$ & AT1 & 9 & 2 & 0.222 & 0.00122 & -1.44751 & 1.41490 \\
\hline $\begin{array}{l}\text { Eurythenes sp. } \\
\text { DISCOLL PAP B }\end{array}$ & AT1 & 8 & 5 & 0.857 & 0.00674 & 0.09834 & 0.12110 \\
\hline $\begin{array}{l}\text { Hirondellea } \\
\text { brevicaudata }\end{array}$ & AT1 & 5 & 1 & - & - & - & - \\
\hline Hirondellea guyoti & AT1 & 11 & 5 & 0.709 & 0.00238 & -1.40298 & -0.97174 \\
\hline \multirow{3}{*}{$\begin{array}{l}\text { Hirondellea sp. nov. } \\
\text { DZMB_2021_0092 }\end{array}$} & AT1 & 4 & 3 & 0.833 & 0.00329 & -0.06501 & 0.25081 \\
\hline & AT2 & 9 & 4 & 0.583 & 0.00101 & -1.51297 & $-1.89165^{\star}$ \\
\hline & com & 13 & 6 & 0.782 & 0.00175 & -1.01207 & $-2.69176^{\star}$ \\
\hline \multirow{3}{*}{$\begin{array}{l}\text { Paracallisoma aff. } \\
\text { alberti }\end{array}$} & AT1 & 7 & 2 & 0.286 & 0.00478 & $-1.62257^{\star}$ & 4.56086 \\
\hline & AT2 & 2 & 2 & 1.000 & 0.00152 & - & - \\
\hline & com & 9 & 3 & 0.417 & 0.00405 & $-1.87639^{\star}$ & 2.51104 \\
\hline \multirow[t]{3}{*}{ Paracallisoma sp. nov. } & AT1 & 4 & 1 & - & - & - & - \\
\hline & AT2 & 9 & 3 & 0.417 & 0.00068 & -1.36240 & $-1.08110^{\star}$ \\
\hline & com & 13 & 3 & 0.295 & 0.00047 & $-1.46801^{\star}$ & $-1.40150^{\star}$ \\
\hline $\begin{array}{l}\text { Pseudonesimus aff. } \\
\text { abyssi }\end{array}$ & AT1 & 6 & 2 & 0.333 & 0.00051 & -0.93302 & -0.00275 \\
\hline \multirow{3}{*}{$\begin{array}{l}\text { Abyssorchomene } \\
\text { distinctus }\end{array}$} & AT1 & 11 & 9 & 0.945 & 0.00254 & -1.21775 & $-7.38058^{\star \star \star}$ \\
\hline & AT2 & 7 & 6 & 0.952 & 0.00261 & $-1.52412^{\star}$ & $-3.70942^{\star \star}$ \\
\hline & $\mathrm{com}$ & 18 & 13 & 0.928 & 0.00260 & $-1.88027^{\star}$ & $-11.98916^{\star \star \star}$ \\
\hline
\end{tabular}

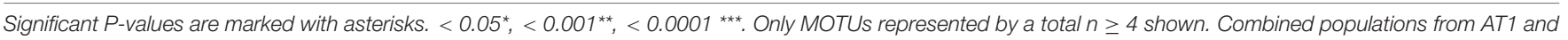
AT2 are presented as "com."

approached the asymptote, so no addition of new species in this assemblage was predicted.

Nevertheless, in another study the species Eurythenes gryllus (Lichtenstein in Mandt, 1822) is reported to be rather an obligate scavenger (Dauby et al., 2001), but as the genus Eurythenes has never been collected at hydrothermal vent areas, it seems to avoid areas with active hydrothermal activity. Dauby et al. (2001) also reported one species of Abyssorchomene [A. nodimanus (Walker, 1903)] as an obligate scavenger, in contrast with Horton et al. (2020b). For A. distinctus, which we captured on both active and inactive site in more or less equal numbers, we might conclude it is resistant enough to environmental conditions to feed at the active site and has no preference for habitat. The genus Hirondellea has been reported to be either an obligate scavenger (Blankenship and Levin, 2007) or a micropredatory browsing type, so scavenging is just an alternative feeding mode for the species (Dauby et al., 2001). In the stomach of Hirondellea antarctica (Schellenberg, 1926) hydrozoans and sea anemones were detected (Dauby et al., 2001). The two described species of Hirondellea presently we captured may be assumed to be facultative scavengers avoiding the active vent sites, whereas Hirondellea sp. nov. DZMB_2021_0092, collected in both locations, may be an obligate scavenger or may also feed on the vent fauna. Little is known about the dominant species in the inactive site-Tectovalopsis fusilus. Similarly to Paralicella this genus is regarded as grouping obligate scavengers (Lowry and De Broyer, 2008), but T. fusilus has so far been collected only once and is known from single individual, so a final decision cannot be drawn about how variable its food composition is.

Our study leads to the conclusions that the scavenging amphipods at the vent fields are not restricted to the locations studied and that only some of the most resistant species may be able to deal with the difficult conditions at the active area. 
TABLE 5 | Analysis of molecular variance (AMOVA) based on pairwise difference among haplotypes; significance calculated by 1,000 permutations of the COI dataset.

\begin{tabular}{|c|c|c|c|}
\hline \multirow[t]{2}{*}{ Source of variation } & \multicolumn{3}{|c|}{ Sampling site (active/inactive) = population } \\
\hline & & Percentage of variation & FST ( $p$-value) \\
\hline \multirow[t]{2}{*}{ Paralicella sp. group 1A DZMB_2021_0085 } & Among populations & -20.00 & $-0.20000(1.00000)$ \\
\hline & Within populations & 120.00 & \\
\hline \multirow[t]{2}{*}{ Paralicella sp. group 2B DZMB_2021_0088 } & Among populations & -3.20 & $-0.03200(1.00000)$ \\
\hline & Within populations & 103.20 & \\
\hline \multirow[t]{2}{*}{ Hirondellea sp. nov. DZMB_2021_0092 } & Among populations & -12.78195 & $-0.12782(1.00000)$ \\
\hline & Within populations & 112.78195 & \\
\hline \multirow[t]{2}{*}{ Paracallisoma aff. alberti } & Among populations & -18.23 & $-0.18226(0.43109)$ \\
\hline & Within populations & 118.23 & \\
\hline \multirow[t]{2}{*}{ Paracallisoma sp. nov. } & Among populations & -11.62791 & $-0.11628(1.00000)$ \\
\hline & Within populations & 111.62791 & \\
\hline \multirow[t]{2}{*}{ Abyssorchomene distinctus } & Among populations & 4.61522 & $0.04615(0.11926)$ \\
\hline & Within populations & 95.38478 & \\
\hline
\end{tabular}

The populations were arranged in active and inactive groups. All p-values are non-significant.

TABLE 6 | Summary of known distribution of presently sampled species indicating the presence at hydrothermal vent areas.

\begin{tabular}{|c|c|c|c|c|}
\hline & Atlantic ocean & Pacific ocean & $\begin{array}{l}\text { Hydrothermal } \\
\text { vents }\end{array}$ & References \\
\hline $\begin{array}{l}\text { Tectovalopsis aff. } \\
\text { diabolus }\end{array}$ & Not recorded & \multicolumn{2}{|c|}{$\begin{array}{c}\text { East Pacific Rise: } 13^{\circ} \mathrm{N} \text { vent site (type locality; } \\
\text { only record so far) }\end{array}$} & $\begin{array}{l}\text { Barnard and Ingram, 1990; Desbruyères et al., } \\
2006\end{array}$ \\
\hline $\begin{array}{l}\text { Tectovalopsis } \\
\text { fusilus }\end{array}$ & Not recorded & \multicolumn{2}{|c|}{$\begin{array}{c}\text { Guerrero, off Punta San Telmo, North East } \\
\text { Pacific (type locality) }\end{array}$} & Barnard and Ingram, 1990 \\
\hline Cleonardo neuvillei & $\begin{array}{l}\text { Canary Islands (type } \\
\text { locality), only record so } \\
\text { far }\end{array}$ & Not recorded & Not recorded & Chevreux, 1910 \\
\hline $\begin{array}{l}\text { Eurythenes } \\
\text { magellanicus }\end{array}$ & $\begin{array}{l}\text { North and South } \\
\text { Atlantic }\end{array}$ & $\begin{array}{l}\text { Cape Horn } \\
\text { (type locality), } \\
\text { Taiwan, } \\
\text { Okinawa Island }\end{array}$ & Not recorded & $\begin{array}{l}\text { Stoddart and Lowry, 2004; Havermans et al., } \\
\text { 2013; Havermans, 2016; Narahara-Nakano } \\
\text { et al., 2018; Horton et al., 2020a }\end{array}$ \\
\hline $\begin{array}{l}\text { Eurythenes sp. } \\
\text { DISCOLL PAP B }\end{array}$ & $\begin{array}{l}\text { Porcupine Abyssal } \\
\text { Plain, Northeast and } \\
\text { Northwest Atlantic }\end{array}$ & $\begin{array}{l}\text { Peru-Chile } \\
\text { Trench, South } \\
\text { East Pacific }\end{array}$ & Not recorded & $\begin{array}{l}\text { France and Kocher, } 1996 \text { (identified as } \\
\text { Eurythenes gryllus ICE-1); Ritchie et al., } 2015 \\
\text { (identified as Eurythenes sp. } 2 \text { HR-2015); } \\
\text { Horton et al., 2020a }\end{array}$ \\
\hline $\begin{array}{l}\text { Hirondellea } \\
\text { brevicaudata }\end{array}$ & $\begin{array}{l}\text { North Atlantic (type } \\
\text { locality) }\end{array}$ & \multicolumn{2}{|c|}{ North of Hawaii, central Pacific } & $\begin{array}{l}\text { Chevreux, 1910; Barnard and Ingram, 1990; } \\
\text { France, } 1993\end{array}$ \\
\hline Hirondellea guyoti & Not recorded & \multicolumn{2}{|c|}{$\begin{array}{l}\text { Hess Guyot in the North Pacific (type } \\
\text { locality), only record so far }\end{array}$} & Barnard and Ingram, 1990 \\
\hline $\begin{array}{l}\text { Haptocallisoma } \\
\text { abyssi }\end{array}$ & $\begin{array}{l}\text { Greenland Sea (type } \\
\text { locality), North Atlantic }\end{array}$ & Not recorded & Not recorded & $\begin{array}{l}\text { Oldevig, 1959; Horton and Thurston, 2015; } \\
\text { Jażdżewska et al., } 2018 \text { (erroneously identified } \\
\text { as Scopelocheirus sp.) }\end{array}$ \\
\hline $\begin{array}{l}\text { Paracallisoma aff. } \\
\text { alberti }\end{array}$ & $\begin{array}{l}\text { Azores (type locality), } \\
\text { North Atlantic }\end{array}$ & Not recorded & Not recorded & Horton and Thurston, 2015 \\
\hline $\begin{array}{l}\text { Pseudonesimus aff. } \\
\text { abyssi }\end{array}$ & $\begin{array}{l}\text { Bay of Biscay (type } \\
\text { locality), North Atlantic }\end{array}$ & $\begin{array}{l}\text { Cedros Trench, } \\
\text { North East } \\
\text { Pacific }\end{array}$ & Not recorded & Chevreux, 1926; Barnard, 1967 \\
\hline $\begin{array}{l}\text { Abyssorchomene } \\
\text { distinctus }\end{array}$ & \multicolumn{2}{|c|}{$\begin{array}{l}\text { South of Palau (type locality), worldwide } \\
\text { distributed in the abyss, the only species } \\
\text { previously recorded in the Indian Ocean }\end{array}$} & $\begin{array}{l}\text { Guaymas } \\
\text { Basin, East } \\
\text { Pacific Rise } \\
13^{\circ} \mathrm{N}\end{array}$ & $\begin{array}{l}\text { Vinogradov, 1993; Bellan-Santini, 1998; } \\
\text { Desbruyères et al., 2006; Jamieson et al., } \\
\text { 2011; Ritchie et al., 2015; Duffy et al., 2016; } \\
\text { Patel et al., 2020; Weston et al., } 2021\end{array}$ \\
\hline
\end{tabular}

Reinforcing the patterns observed in our study, we intend to improve our results by increasing the sample size, placing the traps at different distances from the field and setting a standard for the distance between trap and vent field, and the deployment time. Finally, our results show that the amphipod fauna of the ecosystems of the Central and Southeast Indian Ridges are still widely unexplored and that further studies, particularly of environments such as the inactive and active hydrothermal areas, have great potential for the discovery of more scavenging amphipods. 


\section{DATA AVAILABILITY STATEMENT}

The datasets generated for this study can be found in the Barcode of Life Data System (BOLD) as "DS-INMAC01." All sequences were in addition deposited in GenBank with the accession numbers: COI (MZ197178-MZ197435), 16S (MZ197436-MZ197490), and 18S (MZ197491-MZ197533). Additional information about the analyses presented here is included in the Supplementary Material.

\section{AUTHOR CONTRIBUTIONS}

TCK was the head of the project. TCK and PMA contributed to the conception and design of the study. AMJ performed the morphological studies and identification of the amphipods. KK did the molecular work, constructed the database, and wrote the first draft of the manuscript. All authors contributed to manuscript revision, read, and approved the submitted version.

\section{FUNDING}

AMJ received support in 2019 from the internal funds of the University of Łódź (1.01.01.00.000) to visit DZMB in Wilhelmshaven and verify the identification of the studied collection. KK received a grant from Senckenberg Gesellschaft für Naturforschung (SGN) to work on the Ph.D. (4.02.00065).

\section{REFERENCES}

Altschul, S. F., Gish, W., Miller, W., Myers, E. W., and Lipman, D. J. (1990). Basic local alignment search tool. J. Mol. Biol. 215, 403-410. doi: 10.1016/S00222836(05)80360-2

Bandelt, H. J., Forster, P., and Röhl, A. (1999). Median-joining networks for inferring intraspecific phylogenies. Mol. Biol. Evol. 16, 37-48. doi: 10.1093/ oxfordjournals.molbev.a026036

Barnard, J. L. (1967). Bathyal and abyssal gammaridean Amphipoda of Cedros Trench, Baja California. U. S. Natl. Museum Bull. 260, 1-205; 92 figs.

Barnard, J. L., and Ingram, C. L. (1990). Lysianassoid Amphipoda (Crustacea) from deep-sea thermal vents. Smithson. Contrib. Zool. 449, 1-80. doi: 10.5479/ si.00810282.499

Barnard, J. L., and Karaman, G. S. (1991). The families and genera of marine gammaridean Amphipoda (except marine gammaroids). Part 2. Rec. Aust. Mus. Suppl. 13, 419-866. doi: 10.3853/j.0812-7387.13.1991.367

Beliaev, G. M., and Brueggeman, P. L. (1989). Deep Sea Ocean Trenches and their Fauna. Moscow: Nauka Publishing House.

Bellan-Santini, D. (1998). Crustacés amphipodes des sources hydrothermales: bilan des connaissances. Cah. Biol. Mar. 39, 143-152.

Bellan-Santini, D. (2007). New amphipods of hydrothermal vent environments on the Mid-Atlantic Ridge, Azores Triple junction zone. J. Nat. Hist. 41, 567-596. doi: 10.1080/00222930701262537

Berge, J., and Vader, W. (2001). Revision of the amphipod (Crustacea) family Stegocephalidae. Zool. J. Linn. Soc. 133, 531-592. doi: 10.1111/j.1096-3642. 2001.tb00638.x

Blankenship, L. E., and Levin, L. A. (2007). Extreme food webs: foraging strategies and diets of scavenging amphipods from the ocean's deepest 5 kilometers. Limnol. Oceanogr. 52, 1685-1697. doi: 10.4319/lo.2007.52.4.1685

Boschen, R., Rowden, A., Clark, M., Pallentin, A., and Gardner, J. (2016). Seafloor massive sulfide deposits support unique megafaunal assemblages: implications

\section{ACKNOWLEDGMENTS}

We would like to thank Thomas Kuhn, current Chief-Scientist of the INDEX exploration program; Ulrich Schwarz-Schampera, Chief-Scientist of the INDEX exploration program during the INDEX2018 cruise; and the captain and crew of the RV Pelagia and the ROV team of ROPOS for their help during sampling. Maps and samples presented in this study originate from the INDEX exploration project for marine polymetallic sulfides by the Federal Institute for Geosciences and Natural Resources (BGR) on behalf of the German Federal Ministry for Economic Affairs and Energy. Exploration activities are carried out in the framework and under the regulations of an exploration license with the International Seabed Authority. Thanks to our colleagues at DZMB Wilhelmshaven for their help with the molecular work and data analysis. In this regard special thanks to Sahar Khodami. This publication is number 84 from the Senckenberg am Meer Metabarcoding and Molecular Laboratory and number 61 based on data from the Senckenberg am Meer Confocal Laser scanning Microscope Facility: (SGN-SaMcLSM).

\section{SUPPLEMENTARY MATERIAL}

The Supplementary Material for this article can be found online at: https://www.frontiersin.org/articles/10.3389/fmars. 2021.752360/full\#supplementary-material

for seabed mining and conservation. Mar. Environ. Res. 115, 78-88. doi: 10. 1016/j.marenvres.2016.02.005

Bousfield, E. L., and Hendrycks, E. A. (1995). The amphipod superfamily Eusiroidea in the North American Pacific region. I. Family Eusiridae: systematics and distributional ecology. Amphipacifica 1, 3-59.

Brix, S., Bober, S., Tschesche, C., Kihara, T. C., Driskell, A., and Jennings, R. (2018). Molecular species delimitation and its implications for species descriptions using desmosomatid and nannoniscid isopods from the VEMA fracture zone as example taxa. Deep Sea Res. Part II Top. Stud. Oceanogr. 148, 180-207. doi: 10.1016/j.dsr2.2018.02.004

Campbell, A. C., Bowers, T. S., Measures, C. I., Falkner, K. K., Khadem, M., and Edmond, J. M. (1988a). A time series of vent fluid compositions from $21^{\circ} \mathrm{N}$, East Pacific Rise $(1979,1981,1985)$, and the Guaymas Basin, Gulf of California (1982, 1985). J. Geophys. Res. Solid Earth 93, 4537-4549. doi: 10.1029/ JB093iB05p04537

Campbell, A. C., Palmer, M. R., Klinkhammer, G. P., Bowers, T. S., Edmond, J. M., Lawrence, J. R., et al. (1988b). Chemistry of hot springs on the Mid-Atlantic Ridge. Nature 335, 514-519. doi: 10.1038/335514a0

Chevaldonné, P., Desbruyères, D., and Childress, J. J. (1992). Some like it hot ... and some even hotter. Nature 359, 593-594.

Chevaldonné, P., Desbruyères, D., and Haître, M. L. (1991). Time-series of temperature from three deep-sea hydrothermal vent sites. Deep Sea Res. Part I Oceanogr. Res. Pap. 38, 1417-1430. doi: 10.1016/0198-0149(91)90014-7

Chevreux, E. (1889). Amphipodes nouveaux provenant des campagnes de "l'Hirondelle" 1887-1888. Bull. Soc. Zool. Fr. 14, 283-289.

Chevreux, E. (1908). Diagnoses d'amphipodes nouveaux provenant des campagnes de la "Princesse-Alice" dans l'Atlantique nord. Bull. Inst. Oceanogr. Monaco 117, $1-13$.

Chevreux, E. (1910). Diagnoses d'amphipodes nouveaux provenant des campagnes de la "Princesse-Alice" dans l'Atlantique nord. Bull. Inst. Oceanogr. Monaco 117, $1-113$. 
Chevreux, E. (1926). Diagnoses d'amphipodes nouveaux provenant des campagnes de la "Princesse-Alice," dans l'Atlantique et dans l'Océan Arctique. Lysianassidae. Bull. Inst. Océanogr. Monaco 475, 1-12.

Christiansen, B. (1996). Bait-attending amphipods in the deep sea: a comparison of three localities in the north-eastern Atlantic. J. Mar. Biol. Assoc. U.K. 76, 345-360. doi: 10.1017/S0025315400030599

Collins, P., Kennedy, R., and Van Dover, C. (2012). A biological survey method applied to seafloor massive sulphides (SMS) with contagiously distributed hydrothermal-vent fauna. Mar. Ecol. Prog. Ser. 452, 89-107.

Copilaş-Ciocianu, D., Borko, Š, and Fišer, C. (2020). The late blooming amphipods: global change promoted post-Jurassic ecological radiation despite Palaeozoic origin. Mol. Phylogenet. Evol. 143:106664. doi: 10.1016/j.ympev.2019.10 6664

Corbari, L., and Sorbe, J.-C. (2017). First observations of the behaviour of the deep-sea amphipod Dulichiopsis dianae sp. nov. (Senticaudata, Dulichiidae) in the TAG hydrothermal vent field (Mid-Atlantic Ridge). Mar. Biodivers. 48, 631-645. doi: 10.1007/s12526-017-0788-y

Corbari, L., Durand, L., Cambon-Bonavita, M.-A., Gaill, F., and Compère, P. (2012). New digestive symbiosis in the hydrothermal vent Amphipoda Ventiella sulfuris. C. R. Biol. 335, 142-154. doi: 10.1016/j.crvi.2011.12.005

Costa, F. O., Henzler, C. M., Lunt, D. H., Whiteley, N. M., and Rock, J. (2009). Probing marine Gammarus (Amphipoda) taxonomy with DNA barcodes. Syst. Biodivers. 7, 365-379. doi: 10.1017/S1477200009990120

d'Udekem d'Acoz, C., and Havermans, C. (2015). Contribution to the systematics of the genus Eurythenes S.I. Smith in Scudder, 1882 (Crustacea: Amphipoda: Lysianassoidea: Eurytheneidae). Zootaxa 3971, 1-80. doi: 10.11646/zootaxa. 3971.1.1

Dauby, P., Scailteur, Y., and De Broyer, C. (2001). Trophic diversity within the Eastern Weddell Sea amphipod community. Hydrobiologia 443, 69-86. doi: 10.1023/A:1017596120422

De Broyer, C., Lowry, J., Jażdżewski, K., and Robert, H. (2007). Census of Antarctic Marine Life. Synopsis of the Amphipoda of the Southern Ocean. Part. 1. Catalogue of the Gammaridean and Corophiidean Amphipoda (Crustacea) of the Southern Ocean with distribution and ecological data. Bull. Inst. R. Sci. Nat. Belgique 77, 1-325.

De Broyer, C., Nyssen, F., and Dauby, P. (2004). The crustacean scavenger guild in Antarctic shelf, bathyal and abyssal communities. Deep Sea Res. Part II Top. Stud. Oceanogr. 51, 1733-1752. doi: 10.1016/j.dsr2.2004.06.032

De Busserolles, F., Sarrazin, J., Gauthier, O., Gélinas, Y., Fabri, M. C., Sarradin, P. M., et al. (2009). Are spatial variations in the diets of hydrothermal fauna linked to local environmental conditions? Deep Sea Res. Part II Top. Stud. Oceanogr. 56, 1649-1664. doi: 10.1016/j.dsr2.2009.05.011

Desbruyères, D., Segonzac, M., and Bright, M. (2006). Handbook of deep-sea hydrothermal vent fauna. Denisia 18, 1-544. Linz, Austria.

Drummond, A. J., Suchard, M. A., Xie, D., and Rambaut, A. (2012). Bayesian phylogenetics with BEAUti and the BEAST 1.7. Mol. Biol. Evol. 29, 1969-1973. doi: $10.1093 / \mathrm{molbev} / \mathrm{mss} 075$

Duffy, G., Horton, T., and Billett, D. S. M. (2012). Deep-sea scavenging amphipod assemblages from the submarine canyons of the Western Iberian Peninsula. Biogeosciences 9, 4861-4869. doi: 10.5194/bg-9-4861-2012

Duffy, G., Lawler, S. F., and Horton, T. (2016). Scavenging amphipods of the Angolan deep-sea habitat, with a focus on Abyssorchomene distinctus (Birstein and Vinogradov, 1960) (Amphipoda: Lysianassoidea). J. Crustac. Biol. 36, 417426. doi: 10.1163/1937240X-00002448

Emerson, B. C., Ibrahim, K. M., and Hewitt, G. M. (2001). Selection of evolutionary models for phylogenetic hypothesis testing using parametric methods. J. Evol. Biol. 14, 620-631. doi: 10.1046/j.1420-9101.2001.00306.x

Erickson, K. L., Macko, S. A., and Van Dover, C. L. (2009). Evidence for a chemoautotrophically based food web at inactive hydrothermal vents (Manus Basin). Deep Sea Res. II Top. Stud. Oceanogr. 56, 1577-1585. doi: 10.1016/j.dsr2. 2009.05.002

Excoffier, L., and Lischer, H. E. L. (2010). Arlequin suite ver 3.5: a new series of programs to perform population genetics analyses under Linux and Windows. Mol. Ecol. Resour. 10, 564-567. doi: 10.1111/j.1755-0998.2010.02847.x

France, S. C. (1993). Geographic variation among three isolated populations of the hadal amphipod Hirondellea gigas (Crustacea: Amphipoda: Lysianassoidea). Mar. Ecol. Prog. Ser. 92, 277-287.
France, S. C., and Kocher, T. D. (1996). DNA sequencing of formalin-fixed crustaceans from archival research collections. Mol. Mar. Biol. Biotechnol. 5, 304-313.

Fu, Y. X. (1996). New statistical tests of neutrality for DNA samples from a population. Genetics $143,557-570$.

Gallo, N., Cameron, J., Hardy, K., Fryer, P., Bartlett, D., and Levin, A. L. (2015). Submersible- and lander-observed community patterns in the Mariana and New Britain trenches: influence of productivity and depth on epibenthic and scavenging communities. Deep Sea Res. Part I Oceanogr. Res. Pap. 99, 119-133. doi: $10.1016 /$ j.dsr.2014.12.012

Gamo, T., Chiba, H., Yamanaka, T., Okudaira, T., Hashimoto, J., Tsuchida, S., et al. (2001). Chemical characteristics of newly discovered black smoker fluids and associated hydrothermal plumes at the Rodriguez Triple Junction, Central Indian Ridge. Earth Planet. Sci. Lett. 193, 371-379. doi: 10.1016/S0012821X(01)00511-8

Gerdes, K. H., Kihara, T. C., Martínez Arbizu, P., Kuhn, T., Schwarz-Schampera, U., and Mah, C. L. (2021). Megafauna of the German exploration license area for seafloor massive sulphides along the Central and South East Indian Ridge (Indian Ocean). Biodivers. Data J. 9, e69955.

Gerdes, K. H., Martínez Arbizu, P., Schwarz-Schampera, U., Schwentner, M., and Kihara, T. C. (2019a). Detailed mapping of hydrothermal vent fauna: a 3D reconstruction approach based on video imagery. Front. Mar. Sci. 6:96. doi: 10.3389/fmars.2019.00096

Gerdes, K. H., Martínez Arbizu, P., Schwentner, M., Freitag, R., SchwarzSchampera, U., Brandt, A., et al. (2019b). Megabenthic assemblages at the southern Central Indian Ridge-spatial segregation of inactive hydrothermal vents from active-, periphery- and non-vent sites. Mar. Environ. Res. 151:104776. doi: 10.1016/j.marenvres.2019.104776

German, C. R., and Von Damm, K. L. (2006). "Hydrothermal processes," in The Oceans and Marine Geochemistry, eds H. D. Holland and K. K. Turekian (Amsterdam: Elsevier), 181-222.

Hadziavdic, K., Lekang, K., Lanzen, A., Jonassen, I., Thompson, E. M., and Troedsson, C. (2014). Characterization of the 18S rRNA gene for designing universal eukaryote specific primers. PLoS One 9:e87624. doi: 10.1371/journal. pone. 0087624

Hamby, R. K., and Zimmer, E. A. (1988). Ribosomal RNA sequences for inferring phylogeny within the grass family (Poaceae). Plant Syst. Evol. 160, 29-37. doi: 10.1007/BF00936707

Hammer, O., Harper, D., and Ryan, P. (2001). PAST: paleontological statistics software package for education and data analysis. Palaeontol. Electron. 4, 1-9.

Hashimoto, J., Ohta, S., Gamo, T., Chiba, H., Yamaguchi, T., Tsuchida, S., et al. (2001). First hydrothermal vent communities from the Indian Ocean discovered. Zool. Sci. 18, 717-721. doi: 10.2108/zsj.18.717

Havermans, C. (2016). Have we so far only seen the tip of the iceberg? Exploring species diversity and distribution of the giant amphipod Eurythenes. Biodiversity 17, 12-25. doi: 10.1080/14888386.2016.1172257

Havermans, C., and Smetacek, V. (2018). Bottom-up and top-down triggers of diversification: a new look at the evolutionary ecology of scavenging amphipods in the deep sea. Prog. Oceanogr. 164, 37-51. doi: 10.1016/j.pocean.2018.04.008

Havermans, C., Sonet, G., d'Udekem d'Acoz, C., Nagy, Z. T., Martin, P., Brix, S., et al. (2013). Genetic and morphological divergences in the cosmopolitan deepsea amphipod Eurythenes gryllus reveal a diverse abyss and a bipolar species. PLoS One 8:e74218. doi: 10.1371/journal.pone.0074218

Hendrycks, E. A. (2007). A new species of Valettiopsis Holmes, 1908 (Crustacea: Gammaridea: Lysianassoidea) from abyssal waters off California. Zootaxa 1501, 45-56. doi: 10.11646/zootaxa.1501.1.3

Hessler, R. R., and Sanders, H. L. (1967). Faunal diversity in the deep-sea. Deep Sea Res. Oceanogr. Abstr. 14, 65-70. doi: 10.1016/0011-7471(67)90029-0

Hillis, D. M., and Dixon, M. T. (1991). Ribosomal DNA: molecular evolution and phylogenetic inference. Q. Rev. Biol. 66, 411-453. doi: 10.1086/417338

Horton, T., and Thurston, M. (2009). Hirondellea sindhusagar (Crustacea: Amphipoda: Lysianassoidea), a new deepwater scavenger species from the Indian Ocean, with a key to the genus Hirondellea. Zootaxa 2096, 433-441. doi: 10.11646/zootaxa.2096.1.26

Horton, T., and Thurston, M. (2015). A revision of the genus Paracallisoma Chevreux, 1903 (Crustacea: Amphipoda: Scopelocheiridae: Paracallisominae) with a redescription of the type species of the genus Paracallisoma, the 
description of two new genera and two new species from the Atlantic Ocean. Zootaxa 3995, 91-132.

Horton, T., Thurston, M., Vlierboom, R., Gutteridge, Z., Pebody, C., Gates, A., et al. (2020b). Are abyssal scavenging amphipod assemblages linked to climate cycles? Prog. Oceanogr. 184:102318. doi: 10.1016/j.pocean.2020. 102318

Horton, T., Cooper, H., Vlierboom, R., Thurston, M., Hauton, C., and Young, C. R. (2020a). Molecular phylogenetics of deep-sea amphipods (Eurythenes) reveal a new undescribed species at the Porcupine Abyssal Plain, north east Atlantic Ocean. Prog. Oceanogr. 183:102292. doi: 10.1016/j.pocean.2020.102292

Horton, T., Marsh, L., Bett, B., Gates, A., Jones, D., Benoist, N., et al. (2021). Recommendations for the standardisation of open taxonomic nomenclature for image-based identifications. Front. Mar. Sci. 8:620702. doi: 10.3389/fmars.2021. 620702

Hourdez, S., and Lallier, F. H. (2007). Adaptations to hypoxia in hydrothermalvent and cold-seep invertebrates. Rev. Environ. Sci. Biotechnol. 6, 143-159. doi: 10.1007/s11157-006-9110-3

Ingole, B., and Koslow, J. A. (2005). Deep-sea ecosystems of the Indian Ocean. Indian J. Mar. Sci. 34, 27-34.

Jamieson, A. J., Fujii, T., Mayor, D. J., Solan, M., and Priede, I. G. (2010). Hadal trenches: the ecology of the deepest places on Earth. Trends Ecol. Evol. 25, 190-197. doi: 10.1016/j.tree.2009.09.009

Jamieson, A. J., Kilgallen, N. M., Rowden, A. A., Fujii, T., Horton, T., Lörz, A.-N., et al. (2011). Bait-attending fauna of the Kermadec Trench, SW Pacific Ocean: evidence for an ecotone across the abyssal-hadal transition zone. Deep Sea Res. Part I Oceanogr. Res. Pap. 1, 49-62. doi: 10.1016/j.dsr.2010.11.003

Jamieson, A. J., Solan, M., and Fujii, T. (2009). Imaging deep-sea life beyond the abyssal zone. Sea Technol. 50, 41-46.

Janßen, F., Treude, T., and Witte, U. (2000). Scavenger assemblages under differing trophic conditions: a case study in the deep Arabian Sea. Deep Sea Res. Part II Top. Stud. Oceanogr. 47, 2999-3026. doi: 10.1016/S0967-0645(00)00056-4

Jażdżewska, A. M., Corbari, L., Driskell, A., Frutos, I., Havermans, C., Hendrycks, E., et al. (2018). A genetic fingerprint of Amphipoda from Icelandic waters-the baseline for further biodiversity and biogeography studies. ZooKeys 731, 55-73. doi: $10.3897 /$ zookeys.731.19931

Jażdżewska, A. M., Horton, T., Hendrycks, E., Mamos, T., Driskell, A., Brix, S., et al. (2021). Pandora's box in the deep sea -intraspecific diversity patterns and distribution of two congeneric scavenging amphipods. Front. Mar. Sci. 8:750180. doi: $10.3389 /$ fmars.2021.750180

Kato, S., Takano, Y., Kakegawa, T., Oba, H., Inoue, K., Kobayashi, C., et al. (2010), Biogeography and biodiversity in sulfide structures of active and inactive vents at deep-sea hydrothermal fields of the southern Mariana Trough. Appl. Environ. Microbiol. 76, 2968-2979. doi: 10.1128/AEM.00478-10

Katoh, K., Misawa, K., Kuma, K., and Miyata, T. (2002). MAFFT: a novel method for rapid multiple sequence alignment based on fast Fourier transform. Nucleic Acids Res. 30, 3059-3066. doi: 10.1093/nar/gkf436

Kearse, M., Moir, R., Wilson, A., Stones-Havas, S., Cheung, M., Sturrock, S., et al. (2012). Geneious Basic: an integrated and extendable desktop software platform for the organization and analysis of sequence data. Bioinformatics 28, 1647-1649. doi: 10.1093/bioinformatics/bts199

Kihara, T. C., and Rocha, C. E. F. (2013). First record of Clausidium (Copepoda, Clausidiidae) from Brazil: a new species associated with ghost shrimps Neocallichirus grandimana (Gibbes, 1850) (Decapoda, Callianassidae). ZooKeys 335, 47-67. doi: 10.3897/zookeys.335.5490

Kilgallen, N. M., and Lowry, J. K. (2015). A review of the scopelocheirid amphipods (Crustacea, Amphipoda, Lysianassoidea), with the description of new taxa from Australian waters. Zoosystematics Evol. 91, 1-43. doi: 10.3897/zse.91. 8440

King, N. J., Bailey, D., and Priede, I. (2007). Role of scavengers in marine ecosystems-introduction. Mar. Ecol. Prog. Ser. 350, 175-178. doi: 10.3354/ meps07186

Knox, M. A., Hogg, I. D., Pilditch, C. A., Lörz, A.-N., Hebert, P. D. N., and Steinke, D. (2012). Mitochondrial DNA (COI) analyses reveal that amphipod diversity is associated with environmental heterogeneity in deep-sea habitats. Mol. Ecol. 21, 4885-4897. doi: 10.1111/j.1365-294X.2012.05729.x

Kobayashi, H., Hatada, Y., Tsubouchi, T., Nagahama, T., and Takami, H. (2012). The hadal amphipod Hirondellea gigas possessing a unique cellulase for digesting wooden debris buried in the deepest seafloor. PLoS One 7:e42727. doi: 10.1371/journal.pone.0042727

Kumar, S., Stecher, G., Li, M., Knyaz, C., and Tamura, K. (2018). MEGA X: molecular evolutionary genetics analysis across computing platforms. Mol. Biol. Evol. 35, 1547-1549. doi: 10.1093/molbev/msy096

Larsen, K. (2007). Amphipoda (Crustacea; Peracarida) from the hydrothermal vent system of the Juan De Fuca Ridge, Escabana trough and Gorda ridge, northeast Pacific. Part I. Lysianassidae and Sebidae. Zootaxa 1445, 1-26. doi: 10.11646/zootaxa.1445.1.1

Ledoyer, M. (1986). Crustacés amphipodes gammariens. familles des haustoriidae à vitjazianidae. Faune Madagascar 59, 599-1112.

Legeżyńska, J., Węsławski, J. M., and Presler, P. (2000). Benthic scavengers collected by baited traps in the high Arctic. Polar Biol. 23, 539-544. doi: 10.1007/ s003000000118

Levin, L. A., Mendoza, G. F., Konotchick, T., and Lee, R. (2009). Macrobenthos community structure and trophic relationships within active and inactive Pacific hydrothermal sediments. Deep Sea Res. Part II Top. Stud. Oceanogr. 56, 1632-1648. doi: 10.1016/j.dsr2.2009.05.010

Li, W., and Godzik, A. (2006). Cd-hit: a fast program for clustering and comparing large sets of protein or nucleotide sequences. Bioinformatics 22, 1658-1659. doi: 10.1093/bioinformatics/btl158

Librado, P., and Rozas, J. (2009). DnaSP v5: a software for comprehensive analysis of DNA polymorphism data. Bioinformatics 25, 1451-1452. doi: 10.1093/ bioinformatics/btp187

Lincoln, R. J. (1979). British marine Amphipoda: Gammaridea. London: British Museum (Natural History). Natural History Museum Publications.

Lonsdale, P. (1977). Clustering of suspension-feeding macrobenthos near abyssal hydrothermal vents at oceanic spreading centers. Deep Sea Res. 24, 857-863. doi: 10.1016/0146-6291(77)90478-7

Lörz, A.-N., Tandberg, A. H. S., Willassen, E., and Driskell, A. (2018). Rhachotropis (Eusiroidea, Amphipoda) from the north east Atlantic. ZooKeys 731, 75-101. doi: 10.3897/zookeys.731.19814

Lowry, J. K., and De Broyer, C. (2008). Alicellidae and Valettiopsidae, two new callynophorate families (Crustacea: Amphipoda). Zootaxa 1843, 57-66. doi: 10.11646/zootaxa.1843.1.5

Lowry, J. K., and Kilgallen, N. M. (2014). A generic review of the lysianassoid family Uristidae and descriptions of new taxa from Australian waters (Crustacea, Amphipoda, Uristidae). Zootaxa 3867, 1-92. doi: 10.11646/zootaxa.3867.1.1

Lowry, J. K., and Stoddart, H. E. (2010). The deep-sea scavenging genus Hirondellea (Crustacea: Amphipoda: Lysianassoidea: Hirondelleidae fam. nov.) in Australian waters. Zootaxa 2329, 37-55. doi: 10.11646/zootaxa.2329.1.3

Messing, J. (1983). New M13 vectors for cloning. Methods Enzymol. 101, 20-78. doi: 10.1016/0076-6879(83)01005-8

Michels, J., and Büntzow, M. (2010). Assessment of Congo red as a fluorescence marker for the exoskeleton of small crustaceans and the cuticle of polychaetes. J. Microsc. 238, 95-101. doi: 10.1111/j.1365-2818.2009.03360.x

Modig, H., and Ólafsson, E. (1998). Responses of Baltic benthic invertebrates to hypoxic events. J. Exp. Mar. Biol. Ecol. 229, 133-148. doi: 10.1016/S00220981(98)00043-4

Mohrbeck, I., Horton, T., Jażdżewska, A., and Martínez Arbizu, P. (2021). DNA barcoding and cryptic diversity of deep-sea scavenging amphipods in the Clarion-Clipperton Zone (Eastern Equatorial Pacific). Mar. Biodivers. 51:26. doi: 10.1007/s12526-021-01170-3

Monaghan, M. T., Wild, R., Elliot, M., Fujisawa, T., Balke, M., Inward, D. J. G., et al. (2009). Accelerated species inventory on Madagascar using coalescentbased models of species delineation. Syst. Biol. 58, 298-311. doi: 10.1093/sysbio/ syp027

Nakamura, K., Watanabe, H., Miyazaki, J., Takai, K., Kawagucci, S., Noguchi, T., et al. (2012). Discovery of new hydrothermal activity and chemosynthetic fauna on the Central Indian Ridge at $18^{\circ}-20^{\circ}$ S. PLoS One 7:e32965. doi: 10.1371/ journal.pone. 0032965

Narahara-Nakano, Y., Nakano, T., and Tomikawa, K. (2018). Deep-sea amphipod genus Eurythenes from Japan, with a description of a new Eurythenes species from off Hokkaido (Crustacea: Amphipoda: Lysianassoidea). Mar. Biodivers. 48, 603-620. doi: 10.1007/s12526-017-0758-4

Oldevig, H. (1959). Arctic, subarctic and Scandinavian amphipods in the collections of the Swedish Natural History Museum in Stockholm. Goteb. K. 
Vetenskaps Vitterhets Samhalles Handlingar Sjatte Foljden (Ser. B.) 8, 1-132; 4 pls.

Patel, T., Robert, H., d'Udekem d'Acoz, C., Martens, K., De Mesel, I., Degraer, S., et al. (2020). Biogeography and community structure of abyssal scavenging Amphipoda (Crustacea) in the Pacific Ocean. Biogeosciences 17, 2731-2744. doi: 10.5194/bg-17-2731-2020

Perrone, F. M., Dell'Anno, A., Danovaro, R., Della Croce, N., and Thurston, M. H. (2002). Population biology of Hirondellea sp. nov. (Amphipoda: Gammaridea: Lysianassoidea) from the Atacama Trench (south-east Pacific Ocean). J. Mar. Biol. Assoc. UK 82, 419-425. doi: 10.1017/S0025315402005672

Podowski, E. L., Moore, T. S., Zelnio, K. A., Luther, G. W. III, and Fisher, C. R. (2009). Distribution of diffuse flow megafauna in two sites on the Eastern Lau Spreading Center, Tonga. Deep Sea Res. Part I Oceanogr. Res. Pap. 56, 2041-2056. doi: 10.1016/j.dsr.2009.07.002

Pons, J., Barraclough, T. G., Gomez-Zurita, J., Cardoso, A., Duran, D. P., Hazell, S., et al. (2006). Sequence-based species delimitation for the DNA taxonomy of undescribed insects. Syst. Biol. 55, 595-609. doi: 10.1080/10635150600852011

Puillandre, N., Lambert, A., Brouillet, S., and Achaz, G. (2012). ABGD, automatic barcode gap discovery for primary species delimitation. Mol. Ecol. 21, 18641877. doi: 10.1111/j.1365-294X.2011.05239.x

Ratnasingham, S., and Hebert, P. D. N. (2007). BOLD: the Barcode of Life Data System (http://www.barcodinglife.org). Mol. Ecol. Notes 7, 355-364. doi: 10. 1111/j.1471-8286.2007.01678.x

Ratnasingham, S., and Hebert, P. D. N. (2013). A DNA-based registry for all animal species: the Barcode Index Number (BIN) system. PLoS One 8:e66213. doi: 10.1371/journal.pone. 0066213

Ritchie, H., Jamieson, A. J., and Piertney, S. B. (2015). Phylogenetic relationships among hadal amphipods of the superfamily Lysianassoidea: implications for taxonomy and biogeography. Deep Sea Res. Part I Oceanogr. Res. Pap. 105, 119-131. doi: 10.1016/j.dsr.2015.08.014

Ronquist, F., and Huelsenbeck, J. (2003). MRBAYES 3: Bayesian phylogenetic inference under mixed models. Bioinformatics 19, 1572-1574. doi: 10.1093/ bioinformatics/btg 180

Rozas, J., Ferrer-Mata, A., Sánchez-DelBarrio, J. C., Guirao-Rico, S., Librado, P., Ramos-Onsins, S. E., et al. (2017). DnaSP 6: DNA sequence polymorphism analysis of large data sets. Mol. Biol. Evol. 34, 3299-3302. doi: 10.1093/molbev/ $\mathrm{msx} 248$

Sainte-Marie, B. (1986). Effect of bait size and sampling time on the attraction of the lysianassid amphipods Anonyx sarsi Steele \& Brunel and Orchomenella pinguis (Boeck). J. Exp. Mar. Biol. Ecol. 99, 63-77. doi: 10.1016/0022-0981(86)90 021-3

Schuelke, M. (2000). An economic method for the fluorescent labeling of PCR fragments. Nat. Biotechnol. 18, 233-234. doi: 10.1038/72708

Seefeldt, M., Weigand, A., Havermans, C., Moreira, E., and Held, C. (2017). Fishing for scavengers: an integrated study to amphipod (Crustacea: Lysianassoidea) diversity of Potter Cove (South Shetland Islands, Antarctica). Mar. Biodivers. 48, 2081-2104. doi: 10.1007/s12526-017-0737-9

Shulenberger, E., and Barnard, J. L. (1976). Amphipods from an abyssal trap set in the North Pacific Gyre. Crustaceana 31, 241-258. doi: 10.1163/ 156854076X00035

Shulenberger, E., and Hessler, R. R. (1974). Scavenging abyssal benthic amphipods trapped under oligotrophic central North Pacific Gyre waters. Mar. Biol. 28, 185-187. doi: 10.1007/BF00387296

Sigovini, M., Keppel, E., and Tagliapietra, D. (2016). Open nomenclature in the biodiversity era. Methods Ecol. Evol. 7, 1217-1225.

Stoddart, H., and Lowry, J. (2004). The deep-sea lysianassoid genus Eurythenes (Crustacea, Amphipoda, Eurytheneidae n. fam.). Zoosystema 26, 425-468.

Suchard, M. A., Lemey, P., Baele, G., Ayres, D. L., Drummond, A. J., and Rambaut, A. (2018). Bayesian phylogenetic and phylodynamic data integration using BEAST 1.10. Virus Evol. 4:vey016. doi: 10.1093/ve/vey016

Tajima, F. (1983). Evolutionary relationship of DNA sequences in finite populations. Genetics 105, 437-460.

Tajima, F. (1989). Statistical method for testing the neutral mutation hypothesis by DNA polymorphism. Genetics 123, 585-595.

Tamburri, M. N., and Barry, J. P. (1999). Adaptations for scavenging by three diverse bathyal species, Eptatretus stouti, Neptunea amianta and Orchomene obtusus. Deep Sea Res. Part I Oceanogr. Res. Pap. 46, 2079-2093. doi: 10.1016/ S0967-0637(99)00044-8
Taylor, M. L., and Roterman, C. N. (2017). Invertebrate population genetics across Earth's largest habitat: the deep-sea floor. Mol. Ecol. 26, 4872-4896. doi: 10.1111/ mec.14237

Tempestini, A., Rysgaard, S., and Dufresne, F. (2018). Species identification and connectivity of marine amphipods in Canada's three oceans. PLoS One 13:e0197174. doi: 10.1371/journal.pone.0197174

Thiel, R., Knebelsberger, T., Kihara, T. C., and Gerdes, K. H. (2021). Description of a new eelpout Pachycara angeloi sp. nov. (Perciformes: Zoarcidae) from deep-sea hydrothermal vent fields in the Indian Ocean. Zootaxa 4980, 99-112. doi: 10.11646/zootaxa.4980.1.6

Thornton, B., Bodenmann, A., Pizarro, O., Williams, S., Friedman, A., Nakajima R., et al. (2016). Biometric assessment of deep-sea vent megabenthic communities using multi-resolution 3D image reconstructions. Deep Sea Res. Part I Oceanogr. Res. Pap. 116, 200-219. doi: 10.1016/j.dsr.2016.08.009

Tsurumi, M. (2001). Ecology of Hydrothermal Vents on Three Segments of the Juan de Fuca Ridge, Northeast Pacific. Doctoral dissertation. Victoria, BC: University of Victoria, 325.

Van Dover, C. L. (2011). Mining seafloor massive sulphides and biodiversity: what is at risk? ICES J. Mar. Sci. 68, 341-348. doi: 10.1093/icesjms/ fsq086

Van Dover, C. L., Humphris, S. E., Fornari, D., Cavanaugh, C. M., Collier, R., Goffredi, S. K., et al. (2001). Biogeography and ecological setting of Indian Ocean hydrothermal vents. Science 294, 818-823. doi: 10.1126/science. 1064574

Vinogradov, G. M. (1993). Amphipoda (Crustacea) from thermal vents in the Eastern Pacific. Hydrobiol. J. 26, 77-92.

Vrijenhoek, R. C. (2010). Genetic diversity and connectivity of deep-sea hydrothermal vent metapopulations. Mol. Ecol. 19, 4391-4411. doi: 10.1111/ j.1365-294X.2010.04789.x

Wang, Y., Zhu, C., Sha, Z., and Ren, X. (2019). A new species of Parandania (Amphipoda, Stegocephalidae, Parandaniinae) from the Okinawa Trough. Crustaceana 92, 1427-1434. doi: 10.1163/15685403-000 03944

Weston, J. N. J., Peart, R. A., Stewart, H. A., Ritchie, H., Piertney, S. B., Linley, T. D., et al. (2021). Scavenging amphipods from the Wallaby-Zenith Fracture Zone: extending the hadal paradigm beyond subduction trenches. Mar. Biol. 168:1. doi: 10.1007/s00227-020-03798-4

Wolff, T. (1959). The hadal community, an introduction. Deep Sea Res. 6, 95-124. doi: 10.1016/0146-6313(59)90063-2

Wolff, T. (2005). Composition and endemism of the deep-sea hydrothermal vent fauna. Biol. Mar. 46, 97-104. doi: 10.1007/978-3-319-453 40-8_4

WoRMS Editorial Board (2021). World Register of Marine Species. Available online at: http://www.marinespecies.org at VLIZ (accessed August 2, 2021).

$\mathrm{Wu}, \mathrm{R}$., and Or, Y. Y. (2005). Bioenergetics, growth and reproduction of amphipods are affected by moderately low oxygen regimes. Mar. Ecol. Prog. Ser. 297, 215-223. doi: 10.3354/meps 297215

Zhang, J., Kapli, P., Pavlidis, P., and Stamatakis, A. (2013). A general species delimitation method with applications to phylogenetic placements. Bioinformatics 29, 2869-2876. doi: 10.1093/bioinformatics/ btt499

Conflict of Interest: The authors declare that the research was conducted in the absence of any commercial or financial relationships that could be construed as a potential conflict of interest.

Publisher's Note: All claims expressed in this article are solely those of the authors and do not necessarily represent those of their affiliated organizations, or those of the publisher, the editors and the reviewers. Any product that may be evaluated in this article, or claim that may be made by its manufacturer, is not guaranteed or endorsed by the publisher.

Copyright (๐ 2022 Kniesz, Jażdżewska, Martínez Arbizu and Kihara. This is an open-access article distributed under the terms of the Creative Commons Attribution License (CC BY). The use, distribution or reproduction in other forums is permitted, provided the original author(s) and the copyright owner(s) are credited and that the original publication in this journal is cited, in accordance with accepted academic practice. No use, distribution or reproduction is permitted which does not comply with these terms. 